EstAg 34 (1999) 65-105

\title{
Los catecismos de José de Anchieta
}

El misionero José de Anchieta ha sido prácticamente un desconocido en la catequesis española. Es uno de los casos de «mala suerte», porque al no haber sido célebre, como San Francisco Javier, apenas se ha hablado de él. Y el haber orientado sus pasos hacia Portugal en sus primeros años, y posteriormente haber sido destinado desde Portugal a Brasil, ha hecho que permaneciera ignorado por la mayor parte (por no decir todos) los que de una u otra forma se han ocupado de la catequesis española.

El presente artículo trata de recuperar su figura, que es ensalzada en Brasil (donde fundó, junto con Manuel de Nóbrega una localidad, la actual São Paulo de Piratininga, en $1554{ }^{1}$ ), de manera que la catequesis española pueda conocer lo que llevó a cabo en este terreno. Como casi todos los evangelizadores de la época de los descubrimientos, tuvo que hacer prácticamente de todo, y además de realizar trabajos en el terreno de la catequesis, hubo de aprender la lengua de los indios, el tupi, en la que escribió varias obras, y que sistematizó gramaticalmente y alfabetizó pasándola al grupo de las lenguas salvadas de la desaparición gracias a sus"esfuerzos.

Pero ahora.importa centrar sus desvelos en el terreno de la catequesis, ya que la labor evangelizadora consistía en anunciar la salvación de Jesús, para hacer que aquellos indígenas que jamás habían oído hablar de Él pudiera llegar a prestarle su asentimiento libre. En ese terreno se concentraron sus mejores esfuerzos y es un aspecto éste que conviene no relegar a un segundo plano en medio de otras preocupaciones y trabajos.

\section{José de Anchieta}

Para comenzar por un punto de partida válido, es preciso situar a la persona, en la práctica casi tan desconocido como su obra para la mayoría de los catequetas españoles.

1. S. López Herrera, El Padre José de Anchieta, fundador de São Paulo de Piratininga, Madrid, Cultura Hispánica, 1954. 
José de Anchieta nació en La Laguna (Tenerife), el 19 de marzo de 1534, hijo de Juan de Anchieta y de Mencía Díaz de Clavijo y Llanera. Parece que fue orientado por su padre a hacer estudios en Portugal, y no en España por razón de un antiguo conflicto, que databa de 1515, entre las familias Anchieta y Loyola, emparentadas entre sí. El propio Anchieta no se consideraba castellano, ni español, ni canario, ni portugués, ni brasileño, sino "bizcaino" por su ascendencia.

De muchacho se trasladó a Coimbra, donde estudió humanidades, retórica y parte de filosofía en los jesuitas en cuya comunidad había ingresado con 17 años el 1 de mayo de 1551 . Como solía ser frecuente entonces, numerosos misioneros eran destinados muy jóvenes a sus respectivos destinos, buscando por una parte la mayor eficacia en gente que estuviera bien de salud, y por otra parte la más fácil adaptación a la nueva vida. El suyo no fue un caso excepcional, y como otros jóvenes jesuitas, fue destinado con 19 años a Brasil, aunque todavía no había terminado ni siquiera sus estudios.

En 1553, el 13 de julio, llegó a Brasil, en compañía del jesuita Luis de Grã. Desde Bahía fue destinado por el provincial Manuel de Nóbrega a Capitanía de San Vicente. Ya estaba allí el hermano Vicente Rodríguez, que había llegado a Brasil en la primera expedición de jesuitas, en 1549, y que utilizaba para su apostolado oraciones traducidas por Juan de Azpilcueta Navarro, en una rudimentaria e inicial acomodación de lo que Azpilcueta pudo saber de la lengua de los indígenas. Precisamente con Vicente Rodríguez se embarcó José de Anchieta, en una expedición hacia el sur, con la mala fortuna de que naufragaron en Abrolhos, a la altura de Rio das Caravelas, quedando su viaje en parte frustrado. No así su celo misionero, porque, recogidos por los indígenas, con ellos comenzaron la labor de evangelización que habían previsto desarrollar más al sur. Durante ese tiempo avanza seriamente en el estudio del tupi, la lengua indígena, de manera que es la persona más capacitada entre los colonos portugueses y los jesuitas, para entenderse con los indios; en aproximadamente seis meses consigue saber lo suficiente como para poderse entender, y más adelante la domina con la soltura suficiente para acometer la redacción de una gramática tupi que sistematizara sus conocimientos, y que pudiera ayudar a futuros misioneros.

En 1555, tras dos años de separación, el hermano José (o Irmão José), como era conocido Anchieta, se reencuentra con quien había sido su primer compañero, Luis de Grã, en San Vicente de Piratininga, a donde Grã se ha desplazado desde las poblaciones norteñas. En 1556 circula, manuscrita, su gramática tupi, que, años después, casi a punto de morir Anchieta, será editada en Coimbra (1595) para que el esfuerzo lingüístico no quede valdío; mientras, ha sido utilizada ampliamente en copias manuscritas hondamente apre- 
ciadas. Tal gramática le había sido pedida (en su redacción) por el provincial Nó-brega, a finales del año 1555, conocedor el provincial de que Anchieta tenía mentalmente organizada tal gramática, pero que no la había pasado al papel; la petición se fundamentaba en el hecho de que de esta forma, podría servir en San Vicente de Piratininga a los jesuitas recién llegados a Brasil.

Durante ese mismo año de 1556, Luis de Grã impartió un curso de moral en São Paulo de Piratininga a aquellos hermanos jesuitas que aspiraban al sacerdocio, a fin de suplir la preparación de que aún carecían y capacitarles para la futura actuación sacerdotal, incluido el confesionario, tarea para la que ahora no estaban aún preparados. Esto no equivale a que no realizaran multitud de tareas pastorales, puesto que se veían desbordados por la amplitud de la labor a realizar y la extensión del territorio que pretendían abarcar, para el cual todas las fuerzas eran pocas. También tuvo más adelante al jesuita Quiricio Caxa como profesor en los años 1565-1566, en que se preparaba directamente para la recepción del sacerdocio. Es decir, una larga etapa de actuación pastoral, al cabo de la cual, tras diez años, accede a la ordenación; ésta tuvo lugar en 1566. Al año siguiente fue nombrado superior en Capitanía de San Vicente, dependiente del rector de Rio de Janeiro, a la sazón Nóbrega. El 8 de abril de 1577, en San Vicente, hizo los últimos votos ante el provincial Ignacio Tolosa, aunque aún le faltaban algunos estudios, pero fue admitido en razón de sus dotes personales. El mismo año de 1577 sucedió como provincial a Tolosa, y permaneció como provincial hasta 1587, aunque los últimos años, desde 1583, el cargo lo ejerciera de hecho el visitador Cristóbal de Gouveia.

Mientras, en 1554 Anchieta coincide, por razón de destino, con Pero Correia, portugués que se había trasladado a Brasil como colono, pero que ingresó en la Compañía de Jesús. Consecuencia de su actuación como colono y de su convivencia con los indígenas, Pero Correia predicaba con fluidez a los indios en su lengua, y como consecuencia de su escasa formación y del deseo de llevar a cabo una labor con las mejores garantías de aportar una doctrina bien fundada, Correia pidió a la metrópoli que le hicieran llegar algunos de los libros que entonces gozaban de mayor fama. Solicitó los de Constantino Ponce de la Fuente, que posteriormente fue condenado por la inquisición, pero que, antes de que se produjese tal dictámen, eran extensamente apreciado y leídos con fruición ${ }^{2}$. No tiene, pues, nada de particular esta petición, que

2. CONSTANTINo PONCE DE LA FuENTE publicó tres obras catequéticas: Suma de Doctrina Christiana en que se contiene todo lo principal y necessario que el hombre christiano debe saber y obrar, Sevilla, Juan Cromberger, 1543; Catecismo Christiano compuesto por el Doctor Constantino; añadióse la confesión de un pecador penitente, hecha por el mismo author, s.l., 1547; y Doctrina Christiana en que está comprehendida toda la información que pertenece al hombre que quiere servir a Dios. Por el doctor Constantino. Parte Primera, Sevilla, Juan Canalla, 1548. Ver: 
hay que insertar en la línea de otras muchas de quienes desearon servirse de unas obras que estimaban válidas; tal petición se produce precisamente en mismo año en que äparece en Sevilla la parte primera de la última de sus obras, inconclusa, como consecuencia del proceso inquisitorial; además, se entiende la preferencia por esta obra, puesto que era de las pocas que estaba en lengua vernácula (castellano), que Pero Correia podía leer sin dificultad. Como la preparación de Pero Correia adolecía de ciertas lagunas, el mismo Anchieta se prestó para darles unas lecciones de latín en Piratininga, a fin de que estuviera en condiciones de entender los libros disponibles en esa lengua; sin embargo, el esfuerzo era superior a las fuerzas de Correia.

Hacia 1556 Anchieta ha compuesto su Diálogo da Fe, obra para la que contó con la ayuda de Manuel de Nóbrega y de Luis de Grã, que fueron colaboradores de Anchieta, su autor principal. Entre los años 1554 y 1560 se puede datar la obra denominada Doctrina Cristã, de autoría mucho más compleja, y en la que la participación de Anchieta, como habrá ocasión de ver, resulta bastante menor. Con posterioridad a 1585 , contando algo más de 51 años, Anchieta compuso la tercera obra catequética, su Doctrina autógrafa, de la cual será preciso también hacer unas serie de precisiones.

Pasó los últimos años en Capitanía do Espíritu Santo, interrumpidos por una estancia en Bahía y dos períodos más en Rio de Janeiro, como visitador local. Murió en 9 de junio de 1597, a la edad de 64 años, en Aldeia de Reritiba, ciudad que hoy lleva su nombre, en el distrito de Espíritu Santo ${ }^{3}$.

No cabe duda de que Anchieta fue un hombre destacado, y que sus mismos contemporáneos apreciaron en él a un religioso ejemplar en aquellos momentos en que tan grandes eran las necesidades y tan desproporcionadas a los escasos medios de los misioneros. Pero Rodrigues, que fue provincial en los últimos años de vida de Anchieta, recogió testimonios de quienes convivieron con él; y por encargo del provincial que le sucedió, Fernão Cardim, escribió además una Vida de Anchieta ${ }^{4}$, en la que además de referirse a la gramática, dice respecto a su actuación en la catequesis:

"Trasladou mais o Irmão José o Catecismo, deu principio ao Vocabulário, fez a Doutrina e Diálogo das Coisas da Fe e a Instrução das perguntas para confessar e a que serve para ajudar a bem morrer".

J. R. Guerrero, Catecismos españoles del siglo XVI. La obra catequética del Doctor Constantino Ponce de la Fuente, Madrid, Ins. Sup. de Pastoral, 1969.

3. Amplia nota biográfica en S. LEITE, Monumenta Brasiliae, II, Roma, 1957, 67-71.

4. P. Rodrigues, Vida do Padre José de Anchieta, São Paulo, Loyola, 1978, $2^{\text {a }}$ ed. 
Además, Quiricio Caxa, su antiguo profesor y después provincial, fue el primer biógrafo, en la que denominó Breve relação da Vida e Morte do $P^{e}$. José de Anchieta, redactada en 1598, al año siguiente de la muerte de Anchieta. En ella dice:

“... Chegou a entendê-la e a falá-la com toda a perfeição e compor nela e trasladar as coisas necessárias para a doutrina e catecismos..."

"Foi coisa maravilhosa o fruto grande que com esta sua língua fez em proveito das almas, porque além do exemplo que deu aos mais e fervor que causou neles para aprenderem con diligência, além da muita doutrina e práticas espirituais, assim públicas como particulares; além das muitas confissões que fez como intérprete; além dos muitos que aparelhou para o batismo, para bem morrer, que por seu meio, quanto se pode crer, estão na glória: ajudou a compor a Doctrina, ou foi o principal autor do Diálogo das Coisas da Fé, Confessionário, Instrução para os que hão de ser batizados, e para ajudar os que estão para morrer, de que os Nossos, que não são tão boas línguas, em extremo se têm ajudado e ajudam".

Los dos testimonios se refieren de forma no precisa a sus principales obras catequéticas, con nombres o descripciones que no son exactamente títulos, pero que permiten una cierta identificación y diferenciación de cada una de ellas, o las más importantes. Será preciso volver sobre estos testimonios al hablar de sus escritos. Mientras, queda la sensación de que los testimonios, en la parte reproducida, como también en la no reproducida, son tan encendidamente elogiosos, que parece que todo lo que pasó por sus manos es un ejemplo de perfección. No existe el más mínimo atisbo de sentido crítico (quizá no cabía en el horizonte de quien se proponía trazar un panegírico) ni siquiera para mostrar las limitaciones de sus escritos, inherentes a toda obra humana.

Esta tendencia a la exaltación manifiesta e incluso exagerada, hace acto de presencia no sólo en los testimonios encomiásticos de la época, sino que en la actualidad, la edición de sus obras opta por ese tono laudatorio que hace poca justicia a la realidad de lo que aparece en sus obras, menos exquisitas y perfectas de lo que las juzgan sus impulsores. Y eso mismo hace un poco más difícil el presente estudio de sus trabajos catequéticos, que, juzgados desde una mayor imparcialidad y distancia, pueden aparecen más simples o incompletos. Por descontado que mi intención no es echar por tierra un esfuerzo de difícil estimación; pero ver las cosas en su más desapasionada dimensión puede contribuir a conocer mejor su obra, con las aportaciones que realizó y las limitaciones que implica.

\section{Obras catequéticas con su nombre}

Es difícil hablar de ellas con absoluta precisión. Unas y otras obras se entremezclan, los títulos (o las descripciones que podrían actuar como tales) 
no se refieren siempre con exactitud, o aparecen expresiones equivalentes (que proporcionan una cierta ambigüedad), o se da el título de una parte como un todo (lo que contribuye a la confusión). Además, siendo exigentes en cuanto a la autoría de los diversos escritos, aparecen asignadas a Anchieta cosas que no escribió él.

Voy a comenzar por los testimonios anteriormente reproducidos, que he retocado ligeramente, con la introducción de numeración para lo que podría ser cada escrito y con la introducción de la cursiva para señalar sus títulos aproximados. Con arreglo a este criterio, el testimonio de Pero Rodrigues queda como sigue:

"Trasladou mais o Irmão José 1) o Catecismo, deu principio ao 2) Vocabulário, fez 3) a Doutrina e 4) Diálogo das Coisas da Fe e 5) a Instrução das perguntas para confessar e 6) a que serve para ajudar a bem morrer".

Dispuestos en otro orden estos trabajos literarios, resultan los seis siguientes:

1) o Catecismo

2) Vocabulário (obra no catequética, pues hace referencia a su Gramática tupi, con otro nombre)

3) a Doctrina

4) Diálogo las Coisas da Fe

5) a Instrução das perguntas para confessar

6) a [Instrução] que serve para ajudar a bem morrer,

es decir, solamente cinco trabajos catequéticos diversos.

Si vamos con el segundo testimonio, haciendo la misma acomodación, éste ofrece estos otros datos:

“... Chegou a entendê-la e a falá-la com toda a perfeição e compor nela e trasladar 1) as coisas necessárias para a doctrina e 2) catecismos..."

"Foi coisa maravilhosa o fruto grande que com esta sua língua fez em proveito das almas, porque além do exemplo que deu aos mais e fervor que causou neles para aprenderem con diligência, além da muita doutrina e práticas espirituais, assim públicas como particulares; além das muitas confissões que fez como intérprete; além dos muitos que aparelhou para o batismo, para bem morrer, que por seu meio, quanto se pode crer, estão na glória: 3) ajudou a compor a Doctrina, 4) ou foi o principal autor do Diálogo das Coisas da Fé, 5) Confessionário, 6) Instrução para os que hão de ser batizados, e 7) para ajudar os que estão para morrer, de que os Nossos, que não são tão boas línguas, em extremo se têm ajudado e ajudam". 
Salen, por tanto, siete escritos:

1) as coisas necessarias para a doctrina

2) catecismos

3) ajudou a compor a Doutrina

4) ou foi o principal autor do Diálogo das coisas da Fé

5) Confessionário

6) Instrução para os que hão de ser batizados

7) para ajudar os que estão para morrer.

Comparados ambos resultados, aparecen estas obras:

\begin{tabular}{|c|c|}
\hline Testimonio de Pero Rodrigues & Testimonio de Quiricio CaXa \\
\hline & 1) as coisas necessárias para a doutrina \\
\hline 1) $o$ Catecismo $($ trasladou $=$ tradujo $)$ & $\begin{array}{l}\text { 2) catecismos (chegou a compor e trasla- } \\
\text { dar = llegó a componer y traducir) }\end{array}$ \\
\hline 2) a Doutrina (fez= hizo, escribió) & $\begin{array}{l}\text { 3) a Doutrina (ajudou a compor }=\text { ayudó } \\
\text { a componer) }\end{array}$ \\
\hline \multirow[t]{2}{*}{$\begin{array}{l}\text { 3) Diálogo las Coisas da Fé (fez= hizo, } \\
\text { escribió) }\end{array}$} & $\begin{array}{l}\text { 4) Diálogo das coisas da Fé (ou foi o prin- } \\
\text { cipal autor do = o fue el autor principal) }\end{array}$ \\
\hline & $\begin{array}{l}\text { 5) Instrução para os que hão de ser bati- } \\
\text { zados }\end{array}$ \\
\hline $\begin{array}{l}\text { 4) a [Instrução] que serve para ajudar a } \\
\text { bem morrer }(\mathrm{fez}=\mathrm{hizo})\end{array}$ & $\begin{array}{l}\text { 6) [Instrução] para ajudar os que estão } \\
\text { para morrer }\end{array}$ \\
\hline $\begin{array}{l}\text { 5) Instrução das perguntas para confessar } \\
\text { (fez= hizo) }\end{array}$ & 7) Confessionário \\
\hline
\end{tabular}

Si en la primera enumeración he eliminado la Gramática tupi, hay que hacer lo propio con el Confessionário: siendo un libro destinado directamente a la preparación y celebración del sacramento de la penitencia, no puede decirse que sea propiamente catequético, aunque mantenga un estilo similar, desde el momento que hace un repaso de los mandamientos; pero es claro que se trata sólo de una parte de la doctrina cristiana. Quedan, pues, cuatro escritos en la primera enumeración, la de Rodrigues, y seis en la de Caxa. Parece haber un paralelismo entre ambas series (números 2 a 6); pero en la descripción de Caxa queda desparejada la primera, cuyo título descriptivo ïgura como as coisas necessárias para a doutrina. ¿Es obra distinta?, ¿es idéntica al Catecismo, que sigue a continuación? Podría entenderse de las dos formas, si se identifica doutrina con catecismo, y ambas expresiones se entienden equivalentes a «formación cristiana», por decirlo con una fórmula genérica. Pero también cabe entenderlas como títulos -o sus equivalentes- de forma que Doutrina sea un escrito diverso de Catecismo. 
Pero ese mismo problema, que he planteado para ver la dificultad entre las obras $1^{\mathrm{a}}$ y $2^{\mathrm{a}}$ de la enumeración de Caxa se puede trasladar, tal cual, a las dos series, puesto que a continuación figuran en ambas Catecismo y Doutrina. Y parece que habría que diversificar una de otra. En el testimonio de Pero Rodrigues las expresiones son nítidas: «Trasladou mais o Irmão José 1) $o$ Catecismo, deu principio ao 2) Vocabulário, fez 3) a Doutrina...», es decir, el hermano José [de Anchieta] tradujo el Catecismo, comenzó [a escribir] el Vocabulario [o Gramática], hizo [o escribió] la Doctrina...

Algo semejante ocurre con el testimonio de Quiricio Caxa, quien diferencia (casi siempre) la intervención de Anchieta en escritos diversos: «Chegou a compor nela e trasladar As coisas necessárias para a doutrina e Catecismos (...); ajudou a compor a Doutrina, ou foi o principal autor do Diálogo das coisas da Fé, Confessionário, Instrução para os que hão de ser batizados, e [Instruçâo] para ajudar os que estão para morrer» («Llegó a componer en ella [la lengua tupi] y traducir As coisas necessárias para a doutrina y el Catecismo (...); ayudó a componer la Doctrina, o fue el principal autor del Diálogo das coisas da Fé, Confessionário, Instrução para os que hão de ser batizados, e [Instruçâo] para ajudar os que estão para morrer»).

Si subsiste la duda sobre la identificación o la diversidad de los escritos, también subsiste en cuanto a su intervención, según se consulte uno o otro testimonio, porque no coinciden plenamente, y la expresión «chegou a compor e trasladar», de Quiricio Caxa, se puede aplicär conjuntamente a lo que parecen dos escritos diversos (As coisas necessárias para a doutrina y el Catecismo), o se puede desdoblar en dos afirmaciones, una para cada obra: «Chegou a compor As coisas necessárias para a doutrina, e a trasladar o Catecismo». Entendido así, cuadra la segunda parte de esta frase con la del testimonio de Pero Rodrigues: «Trasladou o Catecismo». Y entonces aparece aún más nítido que As coisas necessárias para a doutrina es un trabajo diverso del Catecismo, y también diverso de Diálogo das coisas da Fé, del que pudo ser bien el autor único, bien el autor principal.

En todo caso, y tras esta multitud de combinaciones, queda claro que los testimonios no son precisos, que no es sencillo saber con exactitud cuántas son las obras catequéticas en las que intervino, y que tampoco es posible tener certeza en cuanto a la intervención de José de Anchieta en cada una de ellas. Aparecen cuatro o seis escritos catequéticos en los que Anchieta ha tenido algún tipo de intervención.

Es preciso dar otro paso más, acudiendo a los manuscritos, para poder precisar con certeza cuántos trabajos catequéticos han pasado por sus manos, y cuál ha sido su aportación en cada uno. Pero antes es obligado hacer una referencia a la edición que conozco y he manejado de sus obras, a partir de las cuales es posible un acceso relativamente sencillo a los manuscritos. 


\section{La edición de las obras de José de Anchieta}

La edición de la totalidad de las obras de Anchieta integra una colección, diseñada en 17 volúmenes, bajo el título general de Monumenta Anchietana. Obras completas do $P^{e}$. José de Anchieta. Los 17 volúmenes están agrupados en tres series, la primera dedicada a la poesía de Anchieta (5 volúmenes), la segunda a la prosa (6 volúmenes), y la tercera a las obras sobre Anchieta (6 volúmenes). Han sido editados por Edições Loyola, en São Paulo. El responsable de las ediciones y autor de las introducciones es Armando Cardoso, al menos para los tomos $8^{\circ}$ y $10^{\circ}$, que son los que se ocupan de los tratados catequéticos, y tengo a la vista ${ }^{5}$.

Cada uno de ambos volúmenes tiene una introducción, seguida del texto de la obra (u obras) correspondiente; en el $8^{\circ}$ la reproducción facsímil precede a la transcripción y notas; el volumen $10^{\circ}$, tomo $1^{\circ}$, sigue ese mismo plan, que, sin explicación aclaratoria, se ve alterado en el volumen $10^{\circ}$, tomo $2^{\circ}$, en el que el facsímil sigue al texto transcrito en lugar de precederlo; además en ese mismo tomo $2^{\circ}$, aparece solamente el facsímil de la Doutrina autógrafa, mientras que no aparece el facsímil del Confessionário.

El volumen $8^{\circ}$ incluye la obra de Anchieta titulada Diálogo da Fé. El volumen 10 , dedica el tomo $1^{\circ}$ a la Doutrina Cristã; y el tomo $2^{\circ}$ a la Doutrina autógrafa, y al Confessionário ${ }^{6}$. Ya he señalado antes mi criterio de excluir el Confesssionário de los escritos catequéticos de Anchieta, que, en esta edición, quedan reducidos a tres: Diálogo da Fe, Doutrina Cristâ, y Doutrina autógrafa.

Cardoso procede de esta forma, siguiendo la pauta de los manuscritos manejados y en parte reproducidos. Pero aparece con evidencia, en las mismas introducciones de Cardoso, que los manuscritos, -tardíos y no originales, excepto uno- han sido manipulados y alterados, por lo que la clasificación de las trabajos catequéticos de Anchieta es posible que no responda del todo a la factura original. Al menos queda la duda. Y desde luego lo que es evidente, y aparecerá más adelante, es que los manuscritos han sido forzados, para acomodarlos a un plan que A. Cardoso se ha trazado, al dar a conocer, transcribir y publicar los tratados catequéticos de Anchieta, plan que no compar-

5. Aparece algún cambio en el proyecto editorial, porque el volumen $8^{\circ}$ (Ed. Loyola, Sâo Paulo, 1988) así lo hace constar en portada, mientras que en cubierta, figura como «10 volume». Por otra parte, el anunciado volumen $9^{\circ}$ debía responder al título de Doutrina Cristã ; y el proyectado volumen $10^{\circ}$ debería incluir el Catecismo. Sin embargo, en el momento de la publicación real, el volumen $9^{\circ}$.(no $10^{\circ}$ ) (Ed. Loyola, São Paulo, 1992), consta de dos tomos, el primero de los cuales se titula Doutrina Cristâ. tomo 1. Catecismo brasílico, y el segundo responde a Doutrina Cristã. tomo 2. Doutrina autógrafa e Confessionário.

6. Ver recensión de los tomos de este volumen $10^{\circ}$, a cargo de José GonZÁlez LuIs en "Estudio Canarios" 29 (1995) 273-278. 
to. Es verdad que a la hora de editar un texto antiguo hay que tomar decisiones, a veces difíciles. Pero no estoy de acuerdo con la forma de proceder de Cardoso, voluntariosa tras el propósito de "reconstrucción" de la obra de Anchieta, pero poco rigurosa en la forma de proceder con los manuscritos, según aparece en las reproducciones facsímiles.

La descripción que hace Armando Cardoso de los manuscritos precisa que son tres los cuadernos atribuidos a Anchieta, que trata de describir en la introducción a la Doutrina da Fé. Estos cuadernos constituyen las tres obras catequéticas de José Anchieta, o vinculadas a su nombre, puesto que la cuestión de la autoría es más compleja.

1. Diálogo das coisas da Fé, también conocida como Diálogo da Fé. Está constituido por un texto en tupi con traducción paralela portuguesa. Al frente del mismo figura un título espurio, posterior y en italiano: «Catechismo in Brasiliano / V. Anchieta». El cuaderno consta de 53 páginas. Las dificultades comienzan al tratar de saber con certeza la localización del mismo. La primera descripción lo señala en el Archivo de la Postulación General de la Compañia de Jesús (APGSI), n. 32, ms. 1731 7; sin embargo, otra descripción señala como signatura la de APGSI, n. 32, ms. 1730 8; por si fuera poca la confusión, la portadilla del texto facsimilar consigna otra tercera signatura:APGSI, n. 29, $\mathrm{ms} .1730^{9}$. (El cotejo y la lectura minuciosa llevan a la conclusión de que hay que dar por buena la primera de las tres signaturas [APGSI, n. 32, ms. 1731] y que las otras son erratas).

2. [Doutrina autógrafa]. Se trata de un cuaderno de 13 hojas, en el que figura el título de «Doutrina do V. Padre José de Anchieta / Escrita da sua mesma / Letra»; pero este título no es original, sino posterior y más bien descriptivo, y ha sido puesto en el cuaderno por el padre João Antônio Andreoni. La obra se encuentra en el Arquivo Romano da Companhia de Jesús (ARSI), opp. NN., 23. La edición anticipa que la obra es una «traducción casi íntegra del Diálogo de la Doctrina Cristiana en tupi, que se encuentra en el conjunto de la Doutrina Cristâ; inmediatamente después de las oraciones y enunciados breves» ${ }^{10}$. Más adelante habrá ocasión de valorar esta apreciación.

3. Doutrina Cristâ. De esta obra existen dos copias, que han de ser descritas por separado.

La $1^{\text {a }}$ copia es la más antigua y también la más deteriorada. Es a su vez copia de un autógrafo primitivo, hoy definitivamente perdido. Carece de título propio; pero el historiador jesuita Serafim Leite le asignó el título inexacto

7. Diálogo da Fe, Sâo Paulo, Loyola, 1988, 9 y 19.

8. Doutrina Cristâ, Sâo Paulo, Loyola, 1992, 19.

9. Diálogo da Fé, Sâo Paulo, Loyola, 1988, 53.

10. Diálogo da Fé, Sâo Paulo, Loyola, 1988, 19. . 
de «Devocionario Brasilico», y ha sido rectificado por el de «Diálogo da Doutrina Cristã». Figura en ARSI, Opp. NN. 22, y su copia en APGSI, n. 33, ms. 1731. Es citada en la edición de Cardoso con la sigla: $\mathrm{DC}_{1}$.

La $2^{\text {a }}$ copia es una copia caligráfica, bien conservada, más reciente, que reproduce el manuscrito anterior. $\mathrm{El}$ texto aparece en tupi, aunque algunos títulos de los diversos apartados consten en portugués. Dispone de un título, tardío, en italiano: «Catecismo in lingua Brasiliana / del V. Anchieta». En su localización vuelven a surgir problemas, porque la descripción inicial da como signatura la de APGSI, ${ }^{\circ} 29$, ms. 1730 11; sin embargo, otra descripción le asigna la signatura APGSI, $\mathrm{n}^{\circ}$ 24, ms. 1730 12. Es citada en la edición de Cardoso con la sigla: $\mathrm{DC}_{2}$.

Es de lamentar que una edición que quiere ser cuidadosa con el texto adolezca de fallos que producen no poca desorientación y que deberían haber sido evitados.

De esta forma, lo que parecían cuatro o seis obras catequéticas, queda reducido a tres, puesto que los manuscritos incluyen en una misma obra o escrito lo que aparece diseminado en las descripciones de Pero Rodrigues o Quiricio Caxa. Al describir, más adelante, el contenido de cada una de ellas, aparecerá hasta qué punto se han integrado los diversos escritos que aparecen como obras diferentes, al menos en la descripción de los dos autores mencionados.

\section{Manipulación de los manuscritos}

El afán perfeccionista de ofrecer una edición lo más completa posible, ha obligado al editor, Armảndo Cardoso, a incurrir en un defecto grave, a mi modo de ver, como es el de manipular los manuscritos. En particular, el problema se concreta de un modo especial con relación a los sacramentos de penitencia y eucaristía, que no están presentes en todas las obras catequéticas asignadas a Anchieta.

Esto genera una situación incómoda, porque al hacer público el texto, el editor del mismo hubiera deseado no encontrar una omisión de este tipo. Y aunque la edición es respetuosa con el principio de mantener la reproducción facsímil sin alteraciones, éstas tienen lugar cuando se pasa a la transcripción de cada uno de los manuscritos. La Doutrina Cristã incluye todos los sacramentos, y por tanto no se produce cambio alguno (El orden en que aparecen los dos sacramentos aludidos es: $1^{\circ}$ penitencia y $2^{\circ}$ confesión).

11. Diálogo da Fé, Sâo Paulo, Loyola, 1988, 19.

12. Doutrina Cristá, Sâo Paulo, Loyola, 1992, 19. 
En Doutrina autógrafa, a continuación del texto propiamente dicho, pero integrado en el manuscrito de signatura ARSI, Opp. NN. 23, aparece una explicación de penitencia y de comunión, precisamente en este orden.

Pero en el manuscrito de Diálogo da Fé faltan estos dos sacramentos al abordar la materia sacramental, y el editor no ha encontrado mejor solución que trasvasar, en la transcripción, la parte de penitencia y comunión, que se encuentra en el manuscrito que responde a la signatura: ARSI, Opp. NN. 22 (y su correspondiente copia en la sigla APGSI, $\mathrm{n}^{\circ} 33$, ms. 1731), que no corresponde a Diálogo da Fé, sino a Doutrina Cristâ. Incluso reproduce el facsímil de lo relativo a estos sacramentos a continuación de la reproducción facsímil de Diálogo da Fé, con su portadilla que avisa de la procedencia de esta parte. Además, aunque esta parte sacramental sigue el orden de: $1^{\circ}$ penitencia y $2^{\circ}$ eucaristía, sin razón alguna que lo justifique, en la transcripción, insertada en el lugar en que consta la ausencia de estos dos sacramentos, los presenta cambiados: $1^{\circ}$ eucaristía y $2^{\circ}$ penitencia.

La argumentación de Cardoso para explicar semejante modo de proceder es doble, aunque en realidad repite los mismos argumentos. En la Introducción a Diálogo da Fé, dice:

«Para explicar a surpreendente lacuna dos diálogos da Confissão e Comunhão, ocurrem diversas razôes: a primeira é o fato, então comum, de se darem autógrafos de Anchieta como relíquias; isto sucedeu com o autógrafo de Évora, que foi privado assim destes dois diálogos, e por isso estes não foram transladados na cópia enviada a Roma, em 1730. A cópia antiga, que ficou no Arquivo da Provincia substituindo o autógrafo dos dois diálogos dados como relíquia, foi transladada na Doutrina Cristã. Levam-nos a esta afirmação os fatos significativos de se encontrarem aí con letra de outro copista, postos no final do livro e formando certa duplicada con dois diferentes diálogos da Confissão e Comunhãâo, ben colocados na sequiência dos Sacramentos e próprios da Doutrina Cristã.

Outra séria razão histórica e literaria é que esses dois diálogos foram os escolhidos por Antônio de Araújo, de preferência aos dois da Doutrina Cristã, apenas tradução de Anchieta, não propriamente composição: a preferência nos Catecismos Brasílicos é sempre para as composições originais do Apostolo do Brasil, como se dá com estes dois sacramentos, explicados exatamente no estilo do Diálogo da Fé.

Outra razão de peso: estes dois diálogos con as orações e o diálogo dos Artigos do Credo ou Suma da Fé, eram o que se exigía bem sabido como preparação dos comungantes, e por isso se separavam dos outros sacramentos, para os ter facilmente à mão, no tupi tan necessario aos missionários, com a preferência acima dita. 
Por todos estes motivos não duvidamos restituí-los ao seu lugar nesta publicacâo primeira dos Diálogo da Fé» 13 .

Me parece que el hecho de una duplicación, y que los sacramentos de penitencia y eucaristía se encuentren al final de la Doutrina Cristã con otra letra no autoriza a deducir con seguridad que esta copia final procede del Diálogo da Fé, y menos aún a desplazarla. Aunque Cardoso afirma que no duda al proceder de esta forma, yo sí que hubiese dudado.

Hay alguna otra manipulación de menor entidad, como es que algunos párrafos que están desordenados en el correspondiente manuscrito, Cardoso los ha reordenado en la correspondiente transcripción, que no es exquisitamente respetuosa con el texto que pretende transcribir ${ }^{14}$. También sucede con cierta frecuencia que aparecen en trascripción algunos titulillos para ciertos apartados que no figuran en el texto facsímil reproducido.

Son muestras de que el editor Armando Cardoso se ha movido con un criterio excesivamente amplio, deseoso de ofrecer al público el mejor texto posible de las obras de Anchieta, pero no se ha atenido con la fidelidad deseable a lo que aparece en los manuscritos. Otra cosa es que en aclaraciones justificara lo que no aparecía en el texto.

\section{Análisis catequético de Diálogo da Fé}

Los testimonios aducidos por Cardoso al prologar la edición muestran a las claras que esta obra surgió de la pluma de José de Anchieta, aunque haya contado para su redacción con la ayuda de Nóbrega y de Luis de Grã, quizá por la aún escasa preparación doctrinal que Anchieta tuviera, o quizá, más probablemente, por la extremada dificultad de hacer una versión a una lengua indígena de conceptos precisos en los que se expresaba el dogma y la fe cristiana: ésta tenía que ser cuidada y transmitida con fidelidad, pero a la vez se imponía la necesidad de que los indios entendieran lo que se les presentaba. No siempre era posible emplear circunloquios, o no era fácil dar con éstos. Por ello está más que justificada la colaboración de Nóbrega y Grã con An-

13. Diálogo la Fé, Sâo Paulo, Loyola, 1988, 50. Parecido argumento, más abreviado, aparece en Doutrina Cristã, Sâo Paulo, 1992, 23, donde dice: «Depois de completa a série dos 7 Sacramentos, acrescentam-se de novo Confissão e Comunhão, tirados claramente do Diálogo da Fé, pois são os mesmos que se encontravam na tradução portuguesa autógrafa, exceto pequenos acréscimos, como dissemos acima. Até o copista do $\mathrm{DC}_{1}$ que os tirou do original é outro, de letra bełn diferente. Por isso non duvidamos de devolvê-los ao Diálogo da Fé, onde estão surpreendentemente faltando.

14. Tal es el caso, en Diálogo da Fé, con las fórmulas de los «casamentos» o desposorios (formula sacramental para el matrimonio), y los «pregôes» o amonestaciones, colocados en un orden en el manuscrito y en otro diferente en la transcripción (ed. citada, p. 162-163). 
chieta. Pero Rodrigues dice que Anchieta "hizo" («fez») esta obra, mientras que Caxa afirma que «fue el autor principal» («ou foi o principal autor»).

Aparece con dos títulos aproximadamente iguales: Diálogo da Fé, y también Diálogo das coisas da Fé, «assim chamado pelos historiadores contemporâneos». El título hace honor a la realidad del escrito, verdaderamente dialogado ${ }^{15}$. Se consideró que se trataba de una obra perdida, aunque en realidad se conservaba en APGSI ( $n^{\circ} 32$, ms. 1.731), en Roma. Ha sido localizada por Paulo Molinari, postulador general de las causas de los jesuitas.

La obra, originalmente en tupi, fue reclamada para que se hiciera llegar a Roma con vistas al proceso de beatificación de Anchieta; eso justificó la copia y la traducción paralela, por lo que es posible conocerla en ambos idiomas. La traducción al portugués fue llevada a cabo por Jacinto de Carvalho, que había sido misionero en Brasil durante 28 años, y que la llevó a cabo en 1730 , certificada por los notarios eclesiásticos que validan la fidelidad del texto y la legitimidad de la versión. Dicha traducción, sin embargo, se efectuó de forma apresurada, por la urgencia de Roma, por lo que el mayor fallo es que proporciona el sentido, pero omite algunos detalles que Carvalho no estimó demasiado importantes. De ahí que la actual edición de São Paulo revise a partir del texto tupi la propia traducción y le añada el texto o los detalles del mismo omitidos por Carvalho, presentados entre corchetes.

La finalidad de la obra era directamente la catequesis destinada a los indios tupis; indirectamente, también fue empleada para que los colonos portugueses pudieran aprender la lengua de los indios, como atestiguan algunas cartas contemporáneas. Está redactada en forma de preguntas y respuestas. Son breves y ágiles, y sólo muy raramente aparece alguna demasiado larga. Las preguntas están precedidas de una "M", y las respuestas de una "D", que señalan que el diálogo discurre entre $\mathrm{M}$ [aestro] y $\mathrm{D}$ [iscípulo]. El primero es quien pregunta y el otro quien responde.

Las apreciaciones que haré (tanto de ésta como de Doutrina Cristã) se limitan al texto en la versión portuguesa.

Su esquema es muy simple, pues responde al siguiente índice:

1. Nombre del cristiano

2. Señal de la cruz

3. Nombre de Jesús (incluye la devoción al Ángel de la guarda, santos y agua bendita)

4. Sacramentos en general Bautismo

15. Sin embargo, la alusión a das coisas da Fé, no permite identificar esta obra, con la que Quiricio Caxa señala en primer lugar de su relación con la alusión genérica de «as coisas necessarias para a doutrina». 
Confirmación 16

Extremaunción

Orden

Matrimonio

5. Pasión (Huerto, Anás, Caifás, Pilato, Herodes, flagelación, corona de espinas, Cruz)

6. Casamientos - Amonestaciones

7. Mandamientos de Dios (en el $3^{\circ}$ se incluye referencia a los de la Iglesia)

8. Padrenuestro.

La primera observación, por más destacada, es que resulta patente la ausencia del credo en la presentación de la fe. Se trata de una parte obligada, que de forma unánime en la catequesis ha precedido a casi todas las explicaciones (salvo las de la señal de la cruz, y del nombre del cristiano). Sin duda resulta difícil de explicar una ausencia de esta índole. y no deja de resultar curioso que tal ausencia no parece preocupar a Anchieta, pues no lo incluye. Sin embargo, con relación al sacramento de la unción de enfermos, en la pregunta $\mathrm{n}^{\circ} 27$, aconseja el empleo del credo: «M. Que há de dizer um quando estiver para morrer? D. "Jesús, María, Credo"»: la respuesta se puede entender sintética, como brevísimas jaculatorias e invocaciones, o también amplia, como una invitación a la recitación completa del credo. No estaba, pues, totalmente ausente de la mente de Anchieta ni de sus colaboradores, Nóbrega y Grã.

Además, es justo reconocer que a lo largo del escrito aparecen referencias salteadas a algunos aspectos inconexos y no sistemáticos que aparecen en el credo (Jesús, verdadero Dios y hombre; Jesús, hijo de Dios; murió por satisfacer por los pecados; María es Madre de Dios; Dios es creador; la pasión, muerte y resurrección de Jesús; el Espíritu Santo; el perdón de los pecados; la resurrección de los muertos). Todo esto se puede encontrar en diversos lugares, en unas ocasiones como breves alusiones y en otras con exposición más amplia. Y es preciso decir que casi aparece todo el credo. Pese a lo cual, es obligado constatar la ausencia de un tratado sistemático, ordenado y completo.

Otra observación es la falta de orden, en el sentido de que el breve tratadito $\mathrm{n}^{\circ} 6$, que contiene los «casamentos» y los «pregões»; debería estar a continuación del sacramento del matrimonio, o mejor integrado en él. No es así en el manuscrito. Sin embargo, Cardoso no ha podido vencer la tentación

16. Ya he manifestado la ausencia de explicaciones sobre penitencia y eucaristía. Creo que es preferible contemplar el texto en su pureza, que aceptar un trasvase bienintencionado para suplir esta carencia. 
de alterar en orden en la transcripción, para unir lo que el texto original presenta como separado. Los «casamentos» recogen una preguntas sobre la voluntad de contraer matrimonio, y dos afirmaciones que expresan la decisión del varón y la mujer de aceptar a su respectivo cónyuge. Los «pregões» constituyen la fórmula de aviso público del matrimonio proyectado, y el requerimiento de que se hagan saber los impedimentos, si existen.

$\mathrm{El}$ apartado $1^{\circ}$, sobre el nombre del cristiano, se centra de inmediato en hablar de Jesucristo, condensando en seis preguntas las afirmaciones básicas de la fe (su origen, que es Dios y hombre, que como Dios es hijo de Dios Padre, y como hombre es hijo de María; que como Dios no tiene cuerpo, ni principio, ni madre; y que como hombre no tiene padre, pues fue concebido sin intervención de varón).

El apartado $2^{\circ}$, sobre la señal de la cruz, habla de su uso, de la forma de hacerla, de su significado, y de las ocasiones de emplearla. Al final del apartado, dedica las tres últimas preguntas a una cuestión tangencial: la reverencia a las imágenes y la honra a los santos en sus imágenes (preguntas 18-20). Estos dos apartados $1^{\circ}$ y $2^{\circ}$ son los más parecidos a los catecismos usuales en el XVI, tanto en España como en Portugal (especialmente el de Marcos Jorge). Puede verse en ellos un vestigio de la formación del mismo Anchieta, que inicia su obra de esta forma convencional, y con una cierta similitud con otros catecismos.

$\mathrm{El}$ apartado $3^{\circ}$ se titula «Do nome de Jesus, e da invocação dos Santos». En efecto, las tres primeras preguntas giran en torno al nombre de Jesús, que nos libra del mal, y la cuestión original de hacer inclinación de cabeza al pronunciarlo. A partir de ahí, las preguntas del apartado giran en torno a María y su nombre; la invocación al Ángel de la Guarda, su existencia y protección; la invocación a los santos (además de lo que había dicho de sus imágenes en el apartado $1^{\circ}$ ), con la cuestión original de la oración que se les debe hacer el día de su fiesta; las seis últimas preguntas versan sobre el agua bendita, y su empleo, entre las que destaca la pregunta original, nada frecuente en los catecismos, de echar agua bendita sobre las sepulturas (no parece que se refiera al empleo de la misma durante las exequias, sino a un uso posterior al entierro, y en cierto modo habitual).

El apartado $4^{\circ}$ es ocupado por los sacramentos; primero en general y después, detallados (salvo los ya aludidos de penitencia y eucaristía). En los sacramentos en general hace una explicación de que sirven para la vida del alma; son presentados siempre como "remedios" o "medicinas" del alma, pues sirven para darle vida; más en particular, se afirma de todos ellos que «perdonan los pecados», lo que no es cierto en la más pura teología sacramental. Esto lleva a la cuestión de si las almas pueden morir, con un doble aserto: no pueden morir pues son inmortales, y las de los condenados arderán eternamente; pero sí pueden morir por el pecado, que mata al alma. Parece obvio que los indígenas percibirían una extraña sensación de desconcierto. 
Al bautismo dedica 38 preguntas, que discurren por el nombre del sacramento, la recepción una sola vez, el hacernos hijos de Dios, los niños que mueren sin bautizar, el bautismo propiamente dicho (el agua y la fórmula sacramental) los efectos del bautismo, el ministro ordinario y extraordinario, la explicación detallada de la liturgia bautismal, y las cuestiones sobre los padrinos. La confirmación, con 20 preguntas, habla del nombre del sacramento y la señal sacramental, los efectos que produce, la confesión explícita de la fe, vuelve (pregunta $13^{a}$ ) sobre los efectos (Dios nos perdona), y la condiciones para confirmarse, la celebración y los padrinos del confirmado. Hace inevitablemente referencia al obispo; y tiene una forma muy original de plantear que sólo se recibe una vez, con la pregunta $17^{\mathrm{a}}$ : «M. Quantos Bispos põem esse óleo [santo na gente]? D. Un só». Hay además una pregunta particular que resulta especialmente reseñable, en la indicación de confesar la fe tras la confirmación, pues afirma que no hay que tener miedo de confesar la fe ante los infieles, en un contexto en que la fe cristiana estaba empezando a arraigar, pues la mayoría eran infieles, y la evangelización era mínima. Pero afirmaciones de este tipo, comunes en los catecismos europeos, en otro contexto llaman la atención, incluso dirigidas a tupis ya cristianos y decididos a recibir la confirmación. Incluso hace referencia a los mártires, hasta entonces desconocidos de los tupis.

Pasando por alto lo insertado sobre penitencia y eucaristía, la extremaunción (31 preguntas) sigue un esquema parecido en que aborda sucesivamente el nombre del sacramento, los efectos, el sujeto que lo debe recibir, la forma de celebración y la atención al moribundo. El orden sacerdotal se trata con más brevedad, en 12 preguntas que discurren por el nombre del sacramento, la misión del sacerdote, el respeto al sacerdote, justificado porque está en lugar de Cristo, y al que hay que obedecer porque lo que dice es por el bien de nuestras almas, y un par de cuestiones finales sobre el hecho de que los sacerdotes permanecen solteros, porque han de vivir como quien está en lugar de Cristo.

El matrimonio tiene un tratamiento más amplio (31 preguntas). Éstas discurren por la celebración, las condiciones para casarse, los fines del matrimonio, los deberes de los esposos, y los pecados en el matrimonio; éstos sólo apuntados con suma delicadeza, pues para evitar el escándalo o la incitación a la malicia, indica que se consulten por parte de los casados directamente en la confesión. Son varios los aspectos dignos de ser subrayados, como la cuestión del matrimonio monógamo ${ }^{17}$, la finalidad del matrimonio que no es otra

17. Las prácticas usuales entre los tupis no contemplaban el matrimonio monógamo, sino una unión aleatoria, especialmente por parte de los jefes de tribu, que podían unirse a una mujer o despedirla a voluntad. Así lo confirma el Confessionario, en Doutrina Cristã, São Pãulo, Loyola, 1992, t. $2^{\circ}, 89$ : «Com quantas mulheres vives?». 
que tener hijos y evitar el amancebamiento, así como que los hijos ayuden en el trabajo del hogar, el evitar las disputas y las palabras injuriosas, pues la mujer no es una esclava, y la situación social, aceptada, de la dependencia de la mujer, sometida o al padre, o al esposo, que está en lugar del padre (pregunta $26^{\mathrm{a}}$ ).

El apartado $5^{\circ}$ del Diálogo da Fé constituye una descripción detallada de la pasión, que aborda la razón del sufrimiento y la muerte, la escena del huerto de los olivos, el interrogatorio ante Anás, y el otro ante Caifás, así como los sucesivos ante Pilato y Herodes, la flagelación y coronación de espinas, y la muerte en la cruz y entierro. Es una parte muy amplia y detallada. Sin duda las posibilidades catequéticas de este relato (en forma de preguntas y respuestas) es grande, por lo vívido que resulta y el planteamiento histórico (y no teórico) que lo destaca del resto del escrito. Sin embargo, se echa de menos que un esfuerzo semejante, aunque fuera resumido, podría haber aparecido sobre la vida y las enseñanzas de Jesús, e incluso sobre los rełatos de la infancia. Pero no aparece nada de esto. Parece que la preocupación no se centra en presentar la actuación de Jesús, sino en incidir en su sacrificio y muerte. La última pregunta deja entrever que la sepultura apunta a la espera de la resurrección; pero nada se dice expresamente de ella. El acento sobre la parte dramática de la entrega de Jesús refleja una posición vinculada al sacrificio y la muerte, con todos los acentos de oblación y sufrimiento. Pero es evidente que esta visión parcial introduce un estilo muy determinado en la catequesis de los indios tupis, y elimina otros aspectos de la vida de Jesús, no ligados a esta visión concreta. La aportación catequética, innegable, está fuertemente limitada por la ausencia de otras facetas de la actuación de Jesús que han sido omitidas. Otras advertencias que aparecen son que, de camino a la crucifixión, incorpora el dato no evangélico de la Verónica ${ }^{18}$, integrado en la piedad popular desde los evangelios apócrifos (pregunta $7^{\mathrm{a}}$ ); además, el detalle de un patetismo extremo, en el sentido de que al extenderlo sobre la cruz tuvieron que forzar sus miembros, para que se aproximaran a los agujeros previstos para los clavos (preguntas $14^{\mathrm{a}}$ y $15^{\mathrm{a}}$ ); y el curioso detalle de que, crucificado desnudo, fue su misma madre María quien, con su propio velo, cubrió la desnudez de su Hijo (pregunta 12a).

En el orden del manuscrito original, en el apartado $6^{\circ}$, siguen los «Casamentos» y los «Pregões», éste último con titulillo propio y perfectamente diferenciado del anterior, Casamentos. La edición de Cardoso los desplaza de lugar, como ya he indicado, y despoja a Pregões de categoría propia al convertirlo en una pregunta más de Casamentos. En ambos casos propone, a títu-

18. Apócrifos Muerte de Pilato, y Venganza del Salvador, XXIV, en A. DE SANTOs (ed.), Los Evangelios apócrifos, Madrid, BAC, 1946, 529 y 558. 
lo de ejemplo, los nombres de Francisco y Caterina, que habrían de substituirse por los nombres de los contrayentes.

El apartado $7^{\circ}$ está constituido por los mandamientos. Dedica a cada uno de los mandamientos de la ley de Dios un número variable de preguntas, que suele ser una docena, o algo más; es decir, están tratados con una cierta extensión y detenimiento. Además, hay seis preguntas globales, introductorias, y cinco finales o recapitulativas.

Me voy a fijar en las preguntas más destacables. Así en el primer mandamiento señala que peca el hechicero, y los que dicen que no hay que guardar la ley de Dios (pregunta 10a): es reflejo de una situación en que el cristianismo se abre paso con dificultad, y acaso con fuertes resistencias, en un ambiente pagano; esto se subraya todavía más con las preguntas siguientes $\left(11^{\mathrm{a}}\right.$ a $17^{\mathrm{a}}$ ), que hablan de que al hechicero se le cree por miedo, se le hacen ofrendas para evitar el mal, y el texto rechaza el invocarle para que cure a los hijos, o señala pecado en los que creen en agüeros de pájaros o ladridos, quien practica el ayuno cuando nace un niño, o quien cree en sueños: breve recorrido por algunas de las creencias y prácticas de la religión indígena.

En el tercer mandamiento de la ley de Dios se insertan de forma breve los mandamientos de la Iglesia, empalmando éstos con la obligación de oir misa. Es curiosa la afirmación de que peca quien impide que acudan a misa sus esclavos y sus hijos (puede entenderse como los hijos del amo, o, más probablemente, como los hijos de los esclavos, también sometidos a esclavitud; pregunta $8^{a}$ ): desconozco si esta referencia obedece a la mentalidad de Anchieta, acostumbrado en Europa, y en Brasil a ver esclavos, o a la situación de los indios, que practicaran la esclavitud con prisioneros de guerra, por ejemplo. En el cuarto mandamiento señala de forma expresa que hay que obedecer al mayoral y al jefe de la aldea (pregunta $4^{a}$ ); aparece la obligación de que la mujer obedezca a su padre y a su marido, como ya había salido antes (pregunta $5^{\mathrm{a}}$ ); y con la misma naturalidad la obligación de que los esclavos han de obedecer a sus amos (pregunta $9^{a}$ ), signo de aceptación social de un hecho, contra el que Anchieta no manifiesta especial repulsa. En el quinto mandamiento declara la licitud de dar muerte a alguien en la guerra (pregunta $4^{a}$ ); indica que el padre ha de pegar a su hijo o a su esclavo para corregirles ; y precisa que cometen un gran pecado contra Dios los antropófagos («os que comem gente», pregunta $\left.12^{\mathrm{a}}\right)^{19}$.

19. J. GonZÁlez LuIs, El proyecto de investigación Padre Anchieta, en G. DíAZ - F. GonzÁLEZ (ed.), Strenae Emmanvelae Marrero oblatae, La Laguna, Publ. Universidad, 525: «El verdadero pecado contra naturam era la antropogafia, pero, además, hay que señalar, como hemos mencionado, otras costumbres inveteradas de orden sociológico-moral como la borrachera, la poligamia, etc, que suponían un serio obstáculo para la cristianización de los indios". Id., Anchieta y los indios de Brasil, en «Fortunate» 5 (1993) 276: «Ciertamente Anchieta estaba obsesionado con la antropofagia. Resulta, en efecto, una constante a lo largo del poema [De gestis Menid de Saa] las continuas referencias a los indios, amantes de peleas, de guerras y hambrientos de carne humana». 
El $8^{\circ}$ y último apartado está dedicado al padrenuestro. Hay que comenzar rehusando que la transcripción haga constar «Pai nosso», cuando el manuscrito (tanto en tupi, como en la traducción portuguesa) dice claramente «Padre nosso». Hace un comentario a la invocación del nombre de Dios, y la alusión al cielo; luego discurre petición a petición; resulta significativa la diferencia que establece entre cristianos y gentiles $\left(1^{\mathrm{a}}\right.$ petición, pregunta $5^{\mathrm{a}}$ y $\left.6^{\mathrm{a}}\right)$, siendo así que hasta no mucho tiempo antes todos los tupis eran integrantes del segundo grupo; pero estimula a que vivan como cristianos, para que, viéndoles, los gentiles se decidan a vivir como cristianos. En la cuarta petición, hay una breve pero sabrosa afirmación (preguntas $10^{\mathrm{a}}$ y $11^{\mathrm{a}}$ ), pues al pedir el alimento señala que la doctrina cristiana es el alimento del alma, pues por ella vive el alma. La petición séptima de vernos libres del mal incluye que nos veamos libres del infierno, de las cobras, las onzas y lo que pueda dañar el cuerpo ( $\ll$ o fogo do inferno, às cobras, às onças, e a tudo que pode fazer mal a nossos corpos»). Dos preguntas finales cierran el apartado centrándose en el «amén».

Hay además otras consideraciones que hacer. Por ejemplo, llama muy poderosamente la atención, la práctica ausencia de la persona del Espíritu Santo, al que el texto se refiere sólo en dos ocasiones, y éstas indispensables: la realización de la señal de la cruz, y la fórmula sacramental del bautismo. En ninguna de ellas podía obviarse su nombre. Pero con estas dos salvedades, no aparece para nada. Podría alegarse que una gran mayoría de catecismos de la época (y de otras épocas) han discurrido por la misma senda, pero es una mala forma de consolarse. La ausencia, ya señalada del Credo, elimina una posibilidad de referirse al Espíritu como Dios, a situarlo en el seno de la Trinidad y a incluir alguna palabra explicatoria. Tampoco aparece al hablar de la encarnación de Jesús, de quien prefiere decir que es hijo de Dios Padre, y que ha sido concebido por María sin intervención de varón.

En contraste a tan llamativo silencio, es obligado hacer referencia a la reiterada alusión al demonio. En efecto, el texto de Diálogo da Fé se refiere a él 6 veces con el nombre de "diablo", y 11 veces con el equivalente de "demonio"; a ellas hay que sumar otras 2 veces en que aparece con la expresión genérica de "enemigo" 20 . Son en total 19 ocasiones. A ellas se podrían añadir las 3 ocasiones en que el texto habla del "infierno", y las otras 3 que emplean la expresión «fogo do inferío», similar. Son 19 oportunidades de referirse al diablo y 6 al infierno, que arrojan un resultado de 25 alusiones. En un texto no excesivamente amplio, es claro que esto supone una constante, que resulta aún más llamativa si se compara con el silencio casi total en torno al Espíritu Santo.

20. No he incluido las otras ocasiones en que la palabra "enemigo" se refiere a algún hombre, como en el caso de la correspondiente petición del padrenuestro sobre el perdón de los enemigos. 
Ya he indicado la referencia a los esclavos en tres ocasiones (llevarles a misa, deben obedecer a su amo, y éste debe pegarles para corregirles). Cabe preguntarse si las tres ocasiones se refieren a los tupis, o a los portugueses, puesto que el momento de la colonización fue testigo de la práctica masiva, y degradante de la esclavitud, que si en Europa se practicaba, aún más en las lejanías de la metrópoli, donde el control era menor, y los abusos más fáciles ${ }^{21}$. Como complemento de esta cuestión, con ocasión de la $2^{a}$ petición del padrenuestro, sobre el cumplimiento de la voluntad de Dios, el texto invita a no cumplir la voluntad del diablo, para no convertirnos en «esclavos del demonio».

Pero si la referencia a los esclavos podría suponer un cierto empleo de Diálogo da Fé entre los portugueses, resulta indudable que la obra contiene tal número de alusiones a la vida de los indios que no es posible olvidar que los destinatarios directos eran los indígenas. Así habla de los hechiceros y de todas las personas que creen en ellos y en agüeros (primer mandamiento) ${ }^{22}$; de cazar pájaros, práctica no exclusiva de los indios, pero en la que éstos eran maestros como medio de supervivencia (padrenuestro, $1^{\text {a }}$ petición); de la obediencia al mayoral o al jefe de la aldea ( $4^{\circ}$ mandamiento); del rechazo de la práctica de la antropogafia ( $5^{\circ}$ mandamiento); del mal del que se desea ver libre quien invoca a Dios, como son las cobras y los onzas ${ }^{23}$. Desconozco si la práctica de echar agua bendita en las sepulturas (a propósito del empleo de la misma), o en las casas (unción de enfermos, pregunta $28^{\text {a }}$ ) era una referencia que pudiera considerarse habitual entre los tupis en la época de la composición de esta obra.

Quiero también resaltar la presencia de la oración en Diálogo da Fé. La explicación expresa es al padrenuestro. Pero además aparecen otra serie de invitaciones a llevar a cabo oraciones en diversos momentos, y además se incluye para cada ocasión una fórmula breve, que bien podría ser aprendida y repetida por los destinatarios del Diálogo. Aparece una invitación a dirigirse al ángel de la guarda (nombre de Jesús, pregunta 12a) ${ }^{24}$; a los santos en

21. De hecho, no mucho tiempo después de Anchieta, otro jesuita, Pedro Claver (15801654) se dedicó en Cartagena de Indias, desde su arribada en 1610, a la atención espiritual y material de los esclavos negros, consecuencia del tráfico organizado desde Africa, tráfico que databa desde fechas tempranas del siglo XVI. La llegada masiva a Brasil de esclavos procedentes de África tuvo lugar a mediados del siglo XVI.

22. J. GonZÁlez LuIS, Anchieta y los indios de Brasil, en «Fortunatae» 5 (1993) 270: «Respecto a los ritos, el misionero tuvo que luchar contra los poderes terribles de los hechiceros y las prácticas idolátricas, encontrando métodos para conjurarlas».

23. En Doutrina autógrafa, c. IV, pregunta 11, hay una alusión semejante a las cobra, onzas y otros males, como consecuencia del pecado original, al que dicho capítulo se refiere. (Ver Doutrina Cristã, t. $\left.2^{\circ}, 33\right)$.

24. «Anjo da minha Guarda, livrai-me hoje e apartai-me de toda a coisa má e fazei que eu viva conforme a vontade de Deus» 
general (nombre de Jesús, pregunta $15^{\mathrm{a}}$ ) 25 ; la invitación a la confianza para acompañar al moribundo (unción de enfermos, pregunta $23^{a}$ ) ${ }^{26}$; las jaculatorias en la hora de la muerte (unción de enfermos, pregunta $27^{\mathrm{a}}$ ) ${ }^{27}$; la petición de perdón dirigida a Dios (Padrenuestro, $5^{\mathrm{a}}$ petición, pregunta $\left.4^{\mathrm{a}}\right)^{28}$.

Para terminar este reflexión sobre Diálogo da Fé, es preciso concluir que se trata de un catecismo incompleto, breve, con un notable nivel de adaptación a las costumbres o prácticas de los indios, pero que, como ocurría con la inmensa mayoría de los que entonces se escribieron, reflejaba la fe católica con los planteamientos teológicos europeos, como no podía ser de otra manera, máxime con las resonancias de la convulsión protestante en Europa. El haber sido redactado en Brasil, en diario contacto con los tupis no privaba a Anchieta y sus colaboradores, Nóbrega y Grã, de las dependencias conceptuales, difíciles de trasvasar a la cultura indígenas. Se percibe la existencia de circunloquios para procurar presentar una determinada afirmación de la fe en términos que pudieran ser asequibles a los destinatarios. Y el rasgo original de tan amplio relato de la pasión (aunque no del resto de la vida y obra de Jesús) le confieren un puesto singular en el panorama catequético del siglo XVI.

\section{Análisis catequético de la Doutrina Cristã}

Mientras el testimonio de Pero Rodrígues indica simplemente que Anchieta «fez» (=hizo, escribió) la Doutrina (identificada como la Doutrina Cristã), el otro testimonio de Quiricio Caxa señala que «ajudou a compor» (=ayudó a componerla o escribirla). Ciertamente no es lo mismo. Y, a la vista del escrito, en la edición ya aludida, y las anotaciones introductorias, hay que dar la razón sin duda a Quiricio Caxa, porque lo que en realidad efectuó Anchieta fue una labor de recopilación y amalgama de diversos documentos, de los cuales sólo una parte se pueden poner bajo su nombre.

Al describir la obra ya hice alusión a los dos manuscritos que de ella se conservan. Paso, por tanto, al análisis más pormenorizado. El editor Armando Cardoso afirma en la presentación de este escrito:

«A Doutrina Cristã é atribuída a Anchieta, principalmente a título de tradução para o tupi, porque ele foi o tradutor principal dos textos apresentados em português, latim, ou espanhol e tambén de textos tupis para serem

25. «Rogai a Deus Nosso Senhor por mim, para que se compadeça de mim».

26. «Vós, Senhor, que morreste para satisfazer por meus pecados me haveis de perdoar nesta hora».

27. «Jesus, Maria, Credo».

28. «Sou um grande pecador, quebrando os mandamentos de Deus que é meu verdadeiro pai, deixando de o amar e honrar, e seguindo somente as minhas maldades». 
corrigidos segundo as regras da Gramática. Igualmente, se lhe deve atribuir por conter a Doutrina partes compostas por ele, como os Preâmbulos da Fé, que aparecem no manuscrito» 29

No comparto en absoluto el criterio de que se le deba atribuir a Anchieta lo que simplemente tradujo; todo lo más se le ha de reconocer y valorar su actuación como traductor. Y el que algunas partes sean obra suya no autoriza a expandir una generosa atribución al todo por la parte. Por otro lado, Cardoso está suficientemente documentado como para ir presentando las diversas asignaciones de los escritos que, en aluvión, constituyen la Doutrina Cristã.

En síntesis, son seis (o siete, según criterios) las partes que integran la Doutrina, con arreglo al siguiente cuadro:

\begin{tabular}{||l|l|}
\hline \multicolumn{1}{|c|}{ Nombre DEL Tratado } & \multicolumn{1}{c|}{ ObSERVACiONES } \\
\hline 1. Instrução para in extremis & $\begin{array}{l}\text { Original de Anchieta. Al escrito sigue, } \\
\text { sin solución de continuidad, y sin títu- } \\
\text { lo propio, otra obra: } \\
\text { Instrução de Catecúmenos, también } \\
\text { original de Anchieta }\end{array}$ \\
\hline 2. Orações & $\begin{array}{l}\text { No hay nada original de Anchieta. Son } \\
\text { oraciones habituales. }\end{array}$ \\
\hline 3. Diálogo da doutrina Cristã & $\begin{array}{l}\text { El autor es Luis de Grã; Anchieta es el } \\
\text { traductor. }\end{array}$ \\
\hline 4. Diálogo dos Preámbulos & Es original de Anchieta. \\
\hline 5. Breve instrução das coisas da Fé & El autor podría ser Pero Correia. \\
\hline 6. Diálogo dos sacramentos & $\begin{array}{l}\text { El autor es Luis de Grã; Anchieta es el } \\
\text { traductor. }\end{array}$ \\
\hline
\end{tabular}

Cardoso añade a esta lista de obras el Confessionario Brasilico, que me parece que es obra independiente, no catequética, y que debe ser tratada aparte. Por eso de incluirla a no incluirla varía la cifra entre 6 y 7 escritos. Como se puede apreciar, la autoría de Anchieta en esta Doutrina Cristã es mínima, reducida a los escritos $1^{\circ}$ y $4^{\circ}$, en tanto que en el resto su aportación, valiosa, es de traductor; y no ha de ser minusvalorada, puesto que Anchieta era el mejor conocedor de la lengua, y llevar a cabo de manera adecuada la versión tupi es una aportación digna de ser tenida en cuenta. Pero es ciertamente distinta de la cuestión de la autoría.

29. Doutrina Cristã, t. $1^{\circ}, 7$. 
Es evidente que la Doutrina Cristã no responde a un plan preconcebido, es decir, que no es una obra pensada con arreglo a unos criterios de exposición de la fe en orden sistemático, ni completo, ni ordenado. Se producen repeticiones, lagunas, saltos; aparecen los diversos escritos en un orden que no es lógico desde el punto de vista de la catequesis, ni se encuentra repetido en ningún otro catecismo. Todo ello es consecuencia de que a esta obra han ido a parar, en plan de recopilación, toda una serie de escritos dispersos, cada uno de los cuales tiene un autor, y responde a un plan concreto y a una necesidad pastoral, y que tienen como denominador común el responder a necesidades catequéticas básicas. El resultado final es un conjunto desordenado y desigual, que en cierto modo acusa esos fallos. Sin embargo, gracias a la recopilación en un conjunto más amplio se han conservado trabajos breves que, de otra forma, se hubieran perdido con bastante facilidad.

En consecuencia, sin ánimo de magnificar la intervención de Anchieta, en una exaltación desmesurada, y sin voluntad de desdibujarla y restarle la importancia que le corresponde, es preciso reconocer que lo que Anchieta aporta en calidad de autor es sólo una parte de la obra, aproximadamente un tercio de la misma. Es preciso, pues, el análisis detallado de cada uno de los escritos con idea de tener una visión más exacta.

\section{1) Instrução para in extremis}

Es una obra perfectamente independiente. Está colocada al principio de la recopilación. Aparece escrita en tupi. El título exacto del manuscrito $\mathrm{DC}_{2}$ es Instrução para in extremis. El escrito es original de Anchieta, y se halla consignado en las dos relaciones de obras (la de Pedro Rodrigues, y la Quiricio Caxa) que lo identifican sin género de duda. La obra consiste en una apretada síntesis, de urgencia (como sugiere el título), para adoctrinar de forma rápida a los indios adultos próximos a morir, y que habían manifestado una cierta voluntad de aceptar el bautismo. Con esta instrucción se obtenía una formación (?), y sobre todo un asentimiento que permitía proceder al bautismo del moribundo, con una cierta tranquilidad de conciencia al haber hecho todo lo humanamente posible.

Consta de seis párrafos, expositivos, breves, cada uno de los cuales termina con una pregunta, a la que la Instrução suministra también la respuesta. Los contenidos son:

1. Invitación a creer en Dios creador.

2. Invitación a creer en Dios remunerador, que salva a los bautizados, y que condena a los no bautizados y a los bautizados que son pecadores.

3. Afirmación de las tres personas de la Trinidad (Este párrafo, excepcionalmente, carece de pregunta final que requiera el asentimiento del indio enfermo). 
4. Invitación a creer en la encarnación de Jesús y su muerte salvadora. La pregunta final podría entenderse, por extensión, que también incluye el párrafo anterior.

5. Invitación al bautismo, con la pregunta que requiere el asentimiento expreso. Hay en el párrafo un cierto automatismo salvífico, puesto que nadie puede ir al cielo si no está bautizado, y en consecuencia se bautiza a las personas para que vayan al cielo. Es verdad que el párrafo $3^{\circ}$ introduce un elemento corrector, en el sentido de que no irán al cielo los bautizados que hayan pecado. Pero, situado in extremis, parece que prima más el deseo de conseguir el consentimiento que permita el bautizo (y con él, la salvación) más que el convencimiento.

6. Invitación a la detestación de los pecados, y el deseo de no volver a ellos. Es lógico que esto aparezca así, puesto que no siempre se seguía de modo seguro la muerte, y por tanto, pastoralmente es válida esta recomendación. Pero recuerda vivamente a la práctica medieval de postergar el sacramento de la penitencia para el momento de la gravedad suma o de la agonía, de forma que las severas penitencias que se imponían quedaran sin efecto, porque no había lugar.

Esta Instrução para in extremis no es literalmente igual a otras empleadas por los jesuitas en su actividad misionera. Pero sí es conceptualmente idéntica. Son las mismas ideas, en síntesis similar, y aparecen en el mismo orden, también en una instrucción breve para los moribundos. La encontramos por partida doble, puesto que la segunda ocasión es copia literal, de la primera, salvo algún leve retoque. Aparece inicialmente en la Doctrina Christiana y catechismo para instrucción de los Indios..., Los Reyes (Lima), António Ricardo, 1584, 18v-23v, con el título de «Plática breve en que se contiene la summa de lo que ha de saber el que se face Christiano». (También es conocido, más frecuentemente como «Catecismo limense», por haber sido redactado con ocasión del III Concilio Provincial de Lima de 1582). La segunda ocasión, trasplantada de la primera, consta en la Doctrina mexicana, redactada por el jesuita Juan de la Plaza, con ocasión del III Concilio Provincial Mexicano de 1585, bajo la presidencia de Pedro Moya de Contreras. Aparece con el título latino de «Modus brevis ad docendum et exhortandum tempore mortis, et declarandum hebetibus quae didicerunt in interrogationibus praeteritis» 30 .

30. Ver L. REsines, Catecismos americanos del siglo XVI, Salamanca, Junta de Castilla y León, 1992, 671 y 647. 
A la instrucción precedente sigue en el manuscrito, sin título propio que lo diferencie, la Instrução de Catecúmenos. Sobre la misma hay que comenzar afirmando que está perfectamente identificada en la relación de escritos que había efectuado Quiricio Caxa, con el título de Instrução para os que hão de ser batizados. Cardoso asegura que la presente es sólo el principio de lo que constituía la formación de los catecúmenos, puesto que para ello se unían tanto la presente Instrução de Catecúmenos, como la Instrução para in extremis, según aparece documentado en las ediciones patrocinadas por Antônio de Araújo (1618) y Bartolomeu de Leão (1686) ${ }^{31}$. Es original de Anchieta, y posiblemente uno de los escritos más remotos, por la necesidad de disponer de una reflexión breve que facilitara una formación sumaria a los indios. Está en tupi, y consta de preguntas y respuestas, éstas relativamente breves en su mayoría. Consta de una parte que se centra en Dios, en quien creer, creador y único, y otra parte constituida por seis preguntas más que insisten en la idea de la Trinidad, con un Dios y tres personas en las que no se distingue el ser de Dios. A todas estas preguntas precede la primera, digna de ser reseñada de modo especial, puesto que afirma que se va al cielo por medio de la recepción del bautismo, santificándose, y viviendo conforme a la ley de Dios.

Cardoso afirma que la Instrução está incompleta, tanto en el manuscrito $\mathrm{DC}_{1}$, como en el manuscrito $\mathrm{DC}_{2}$, que es copia del anterior. La certeza la arrojan otras copias manuscritas, localizadas en el British Museum, que contienen la instrucción completa. Según estas copias del British Museum, además de esta parte primera sobre la Trinidad, el texto primitivo abordaba la Encarnación de Jesús, su pasión y muerte, la Resurrección, la venida del Espíritu Santo, la Iglesia, la confesión y la comunión.

Se entiende perfectamente que la totalidad de esta materia, aunque no fuera amplia en exceso, pudiera constituir una formación básica para adultos que no se encontraban en peligro de muerte, y que su preparación llevara un tiempo algo extenso, porque no se trataba simplemente de que repitieran lo que se les presentaba (aunque fuera en su lengua), sino que lo entendieran y lo aceptaran. Pero el texto mutilado, referente sólo a unas preguntas introductorias sobre Dios, y otras cuantas sobre la Trinidad, dan una pobre idea de lo que tuvo que ser esta obra de Anchieta, síntesis de los más notables conocimientos cristianos, puestos en forma que pudieran ser captados por los indígenas.

31. A. Araúso, Catecismo na Língua Brasílica No Qual se Contém a Summa da Doutrina Cristã..., Lisboa, Pedro Crasbeek, 1618; B. DE LEÃo, Catecismo Brasílico Da Doutrina christãa..., Lisboa, Miguel Deslandes, 1636. 


\section{2) Orações}

Lo que constituye el siguiente apartado de este conglomerado de escritos catequéticos son las oraciones. El texto aparece mutilado, puesto que se inicia hacia la mitad del credo. Es fácil suponer que había sido precedido de otros formularios. Esta edición patrocinada por Cardoso acude al método voluntarioso de suplir la parte que falta echando mano de las ediciones efectuadas por Aráujo y Leão ${ }^{32}$. De acuerdo con este cotejo, faltan la señal de la cruz, el padrenuestro, el avemaría, y el inicio del credo. Siguen -ya en los manuscritos $\mathrm{DC}_{1}$ y $\mathrm{DC}_{2}$ - el resto del credo, los mandamientos de Dios, los de la Iglesia, los sacramentos, las obras de misericordia, la confesión general ${ }^{33}$, la salve, los artículos de la fe, los pecados mortales (o capitales), las virtudes contrarias a ellos, las potencias del alma, los sentidos corporales, las virtudes teologales y cardinales, los dones del Espíritu Santo y las Bienaventuranzas.

Esta parte, constituye, en realidad, una simple «cartilla de la doctrina cristiana», que, salvo las dos inclusiones señaladas en nota, para nada se diferencian del resto de las cartillas al uso. No se puede encontrar en ella nada que, en puridad, sea original de Anchieta, puesto que todos estos formularios eran lugares comunes de toda la formación religiosa, y constituían la base de la misma, especialmente en lo que suponía la repetición hasta conseguir que se supieran todos los formularios, para poder pasar después a explicarlos. No son tampoco raros los casos en que toda la formación que suministran algunos catecismos elementales, y sobre todo las «cartillas de la doctrina cristiana» no incluían más que estos formularios, sin ningún tipo de explicación, bien porque se estimaba suficiente con repetirlos, bien por la dificultad de traducir a una determinada lengua todos y cada uno de sus enunciados.

En el presente caso, lo más que se puede asignar a Anchieta es la labor de traducción de tales formularios en su condición de "lengua" competente para el tupi.

\section{3) Diálogo da Doutrina Cristã.}

Nos encontramos ante la que podría ser estimada como la obra más importante de toda la recopilación reunida en este escrito, por ser la más completa y la más extensa. El editor Armando Cardoso señala dos posibles vinculaciones de este Diálogo da Doutrina Cristã, que no coinciden enteramente.

Por un lado indica la relación entre Diálogo da Doutrina Cristã y Doutrina Autógrafa, de la siguiente forma:

32. Ver nota anterior.

33. En $\mathrm{DC}_{1}$ incluye, además, el «Domine, non sum dignus», y el «In manus tuas Domine», formularios que no suelen ser habituales en los catecismos. 
«Anchieta o traduziu [o Diálogo da Doutrina Cristã] em português, com poucas diferenças, tradução conservada em autógrafo (DA [=Doutrina Autógrafa])» ${ }^{34}$.

De esta forma, Doutrina Autógrafa constituye una traducción modificada de Diálogo da Doutrina Cristã. La otra información la relaciona con Instrução de Catecúmenos así:

«Esta Instrução de Catecúmenos, $1{ }^{\text {a }}$ Suma da Fé, foi despois ampliada pelo P. Luís de Grã em diálogo português, que fez traduzir por Anchieta ao tupi; essa $2^{\text {a }}$ Summa da Fé, muito mais longa, abrange cerca de 200 itens e chamou-se Diálogo da Doutrina Cristã, e se atribuiu no norte ao P. Grã, ja Provincial e ardoroso propagador desse diálogo, diferente do Diálogo da Fé ou das coisas da Fé, original de Anchieta» 35.

Según este doble aserto, en orden cronológico, lo primero fue la Instrução de Catecúmenos, que, ampliada por Grã, dio lugar al Diálogo da Doutrina Cristã; éste a su vez, traducido al portugués y modificado constituye la Doutrina Autógrafa. A mi parecer, la interpretación no es válida, puesto que la Instrução de Catecúmenos, mutilada, no permite una hipótesis tan cabal, aunque se conozca por dónde discurría su contenido. Creo que es más exacto tratar de establecer la vinculación entre Diálogo da Doutrina Cristã y Doutrina Autógrafa, dejando de lado la otra obra. En efecto, como se verá más adelante, estas dos obras son muy parecidas: siguen el mismo orden de los diferentes apartados, y, dentro de ellos, aproximadamente el mismo orden de las preguntas y de las ideas. Hay, sin embargo, diferencias abundantes entre una y otra, que no se pueden desconocer. Pero es cierto que hay que seguir manteniendo la similitud fundamental.

En cualquier caso, el autor de Diálogo da Doutrina Cristã es Luis de Grã, y de nuevo hay que asignar a Anchieta el papel secundario de traductor al tupi. Y su intervención, todo lo importante que se quiera, no deja de ser una intervención de menor importancia.

La totalidad del Diálogo da Doutrina Cristã está integrada por nueve apartados, que son:

1. La Trinidad

2. La creación del mundo

3. La creación y pecado de Adán

4. La encarnación de Jesús

5. La pasión

34. Doutrina Cristã, Ed. Loyola, São Pãulo, 1992, tomo $1^{\circ}, 22$.

35. Ibid., 135. 


\section{Resurrección, Ascensión y Pentecostés}

7. El juicio

8. El limbo y purgatorio

9. La Iglesia.

Todo ello está presentado por preguntas y respuesta, entre M (Maestro) y D (Discípulo), con un número desigual de preguntas para cada apartado.

Creo que olvidando la posible vinculación con Instrução de Catecúmenos, se puede hablar de una obra de nuevo cuño, original de Grã, que constituye un catecismo explicativo, relativamente amplio, fácil en su presentación metodológica por preguntas no demasiado largas, que fue traducido por Anchieta al tupi. Era totalmente lógico que Luis de Grã pusiera interés en que se difundiese, por varias razones: $1^{\mathrm{a}}$ porque él era el autor, y se sentía satisfecho con su escrito; $2^{a}$, porque, traducido por Anchieta, estaba garantizada la calidad de la versión y que fuera entendido por los indígenas; $3^{\mathrm{a}}$ porque en su condición de provincial tenía que tomar la decisión de que se utilizara un texto catequético con preferencia a otros, para la enseñanza normal (Otra cosa distinta era la atención «in extremis» a los moribundos, o a los catecúmenos adultos, para los cuales disponían los jesuitas ya de otros escritos); $4^{\mathrm{a}}$ porque no era cuestión de estar escribiendo y traduciendo constantemente instrumentos catequéticos nuevos, sino concentrar los esfuerzos y perfeccionarlos hasta un nivel satisfactorio, para poderlos usar de forma cotidiana.

De ahí que, siendo la obra original de Grã, no proceda comentar su contenido catequético, al centrarme en los escritos de Anchieta. Sí lo haré, con cierto detenimiento, al examinar después la Doutrina Autógrafa, por la mayor intervención que en la misma tuvo José de Anchieta. Mientras, queda asignada a Luis de Grã, de manera que el escrito catequético más notable de este conglomerado de obras también se distancia de Anchieta como su autor ${ }^{36}$.

\section{4) Diálogo dos Preâmbulos da Fé}

Hay que hacer una advertencia indispensable al estudio de esta parte: el título precedente no consta en el manuscrito, sino que es fruto de la intervención de Cardoso como responsable de la edición y la transcripción de la obra.

El escrito está constituido por una serie de diálogos sobre tres puntos: 1) el nombre de cristiano; 2) la señal de la cruz; y 3) el nombre de Jesús y la invo-

36. La transcripción de Cardoso es deficiente en algunos puntos. Por ejemplo, altera algún titulillo con relación al manuscrito reproducido, que dice: «Diálogo da doutrina Christaá. / Capit. $1^{\circ} / \mathrm{Da}$ Santissima Trindade», mientras la transcripción (p. 157) es: «Capitulo $1^{\circ}$ / Diálogo da doutrina cristã». Además, en el apartaḍo $6^{\circ}$, sobre la resurrección, ascensión y Pentecostés, la pregunta $21^{a}$ omite la respuesta, que en el manuscrito es, para el tupi: «D. Oemimotára rupíñe», y para el portugués: «D. Por su própia vontade». 
cación a los santos. Inmediatamente surge el recuerdo de los apartados iniciales de la primera obra de Anchieta estudiada: el Diálogo da Fé. En efecto, hecho el cotejo correspondiente con los tres apartados de aquel escrito, aparece que las nueve preguntas de Diálogo da Fé sobre el nombre de cristiano se corresponden con las nueve aquí transcritas; las 20 preguntas sobre la señal de la cruz están prácticamente repetidas en las 20 paralelas; y lo mismo ocurre con las 26 preguntas sobre el nombre de Jesús y la invocación a los santos, casi iguales en ambos escritos.

No es fácil encontrar una explicación convincente para que el compilador del manuscrito comenzara a copiar algunos apartados del Diálogo da Fé, y se haya detenido en los tres primeros. Quizá el carácter de amalgama escasamente ordenada que preside todo el documento, desde el principio hasta el final, hace que desistiera de continuar transcribiendo lo que había iniciado. Tampoco puso cuidado el amanuense en señalar el título de la obra de la que estaba copiando, quizá porque se trataba de copias manuscritas, $\mathrm{y}$, más probablemente, porque ni siquiera disponía de título como tal: eran copias que circulaban de mano en mano entre los jesuitas y el compilador de ellas, no demasiado cuidadoso, copió una parte, pero no todo.

Lo dicho sobre la estimación catequética de este escrito de Anchieta, que aparece en Diálogo da Fé completo, y que aparece aquí de manera fragmentaria, evita la repetición, con la salvedad de que la mutilación de las cinco partes no reproducidas deja incompleto y vacilante en esta oportunidad el escrito primitivo.

\section{5) Breve Instrução das coisas da Fé}

El estudio introductorio de Cardoso indica que se trata de una exposición en prosa, sobre una serie de temas catequéticos: Dios, la Trinidad, la creación, el pecado, la encarnación, María, la muerte, resurrección y ascensión de Jesús, el juicio final y una exhortación conclusiva. También indica que, al no asignarla a José de Anchieta los biógrafos contemporáneos, podría asignarse la autoría a Pero Correia. De esta forma, tampoco hay que hacer demasiados comentarios a una obra que no es de Anchieta.

El desarrollo del escrito consta de una serie de frases seguidas que, en la transcripción prologada por Cardoso, han sido numeradas, hasta un total de 39. De ellas, sin embargo, hay que hacer tres advertencias, en el sentido de que las frases que aparecen con los ordinales $1^{\circ}, 2^{\circ}$ y $36^{\circ}$ incluyen una pregunta: La $1^{\text {a }}$ sobre creer en Dios; la $2^{\mathrm{a}}$ sobre no llamar con el nombre de Dios a ninguna otra cosa; y la $36^{a}$ sobre si el destinatario de esta enseñanza cree todo lo anterior. En la frase $37^{\mathrm{a}}$ aparece, velado, el interlocutor que habla con el indí- 
gena: «Eu aplacarei a Deus agora...» (= «Yo pediré a Dios ahora...»). Se refiere, sin duda al sacerdote, que, tras haber llevado a cabo la enseñanza, suplicará a Dios que para que el indígena sea su hijo, salga de él el demonio, y deje de ser su esclavo, y termine por reconocer a Dios.

\section{6) Diálogo dos Sacramentos}

Con arreglo a los datos proporcionados por Cardoso en su introducción, estos comentarios se deben probablemente a la autoría de Luis de Grã, mientras que Anchieta ve reducido su papel al de traductor principal. Es un tratado completo, por preguntas y respuestas, que abarca los siete sacramentos, más unas cuantas preguntas (nueve, en total) introductorias a los sacramentos. De nuevo se esfuma la aportación de Anchieta, reducida a su labor de intérprete, pero que no ocupa el puesto de autor, y al que no se pueden asignar las afirmaciones que aparecen sobre los sacramentos, ni, en consecuencia, valorar su aportación catequética. Es cierto que en algunas de las preguntas que aparecen sobre los sacramentos en Diálogo da Fé se encuentra un cierto paralelo con algunas otras de las redactadas en esta ocasión por Luis de Grã; pero un parecido ocasional no lleva a sacar conclusión alguna, más allá de la coincidencia por estar tratando de la misma materia e inmersos Grã y Anchieta en el mismo ambiente.

Haciendo balance, la aportación de Anchieta resulta escasa en esta obra que con el título de Doutrina Cristã se pone bajo su nombre : la autoría de Instrução para in extremis y de Instrução de Catecúmenos; y la autoría (repetida y mutilada) de los Diálogo dos Preâmbulos da Fé. En el resto, se limita a actuar de traductor de escritos, la mayor parte de ellos de Luis de Grã, más uno atribuido a Pero Correia. En estas condiciones, no es posible hacer un balance que exalte la intervención de Anchieta. Más aún, el carácter desigual, nada ordenado, y falto de plan del conjunto de la obra desmerecen en cuanto a valoración catequética. Se adivina un afán práctico de reunir en un solo documento unos cuantos trabajos sueltos y aislados, para poder emplearlos a conveniencia del usuario, pero sin que exista un plan, ni se puedan resaltar sus valores catequéticos, dispersos y de escasa relevancia. Y, por descontado, hay que asignarlos a los respectivos autores, pero en muy poca medida a José de Anchieta.

\section{Análisis catequético de Doutrina autógrafa}

Al hablar del Diálogo da Doutrina Cristã, integrado en el conjunto del manuscrito abordado en el apartado anterior, y conocido con el nombre de Doutrina Cristã, ha habido ocasión de reproducir las palabras del editor Armando Cardoso, quien dice: 
«Anchieta o traduziu [o Diálogo da Doutrina Cristã] em português, con poucas diferenças, tradução conservada em autógrafo (DA [= Doutrina Autógrafa])» 37 .

Vimos también que Cardoso quiere conectar estas dos obras con la Instrução de Catecúmenos, y lo hace de la siguiente forma en la introducción de la Doutrina Autógrafa:

«Sendo uma quase-retroversão do Diálogo da Doutrina Cristã, a Doutrina Autógrafa deriva proximamente desse sumário da fé, redigido pelo Pe. Luís de Grã e traduzido para o tupi por Anchieta. Como o Própio Diálogo da Doutrina Cristã é uma ampliação da Instrução de Catecúmenos, é nesta que vamos encontrar a origem remota da Doutrina Autógrafa» 38.

Y un poco más adelante, se ratifica en la misma idea, con algún matiz adicional:

«Antes de o Pe. Luís de Grã partir para a Bahia em 1560, o Diálogo da Doutrina Cristã já fora revisado por ele e ampliado en nove capítulos, e traduzido por Anchieta para o tupi, fazendo parte do conjunto da Doutrina Cristã» ${ }^{39}$.

A mí me parece que las cosas no tienen que remontarse a un origen tan lejano, sino que es cierto el parecido de Doutrina Autógrafa con Diálogo da Doutrina Cristã, pero no es preciso remontarse a la Instrução de Catecúmenos. En forma de cuadro, sintetizo los contenidos más notables de cada una de las obras que podrían tener un cierto parecido, de forma que queden también claras las diferencias entre ellas: (Véase página siguiente).

Es claro que el paralelismo es casi total en las dos últimas columnas, que son las que están emparentadas entre sí, mientras que en el caso de la referencia de Doutrina Autógrafa a las dos primeras columnas es sólo circunstancial, puesto que están hablando de temas catequéticos, pero ni aparecen todos, ni en el mismo orden, ni con la misma extensión. Ver, por tanto, que la Instrução de Catecúmenos (o la otra) es un precedente de la Doutrina Autógrafa es disponer de una buena voluntad poco exigente con los datos que las obras mismas están aportando con el examen de su contenido. Creo que sólo se puede hablar del paralelismo de las dos últimas columnas, es decir, lo que aparece integrado en Doutrina Cristã, y la obra autónoma, al menos porque ha sido conservada en otro manuscrito, con el título de Doutrina Autógrafa.

37. Doutrina Cristã, Ed. Loyola, São Pãulo, 1992, tomo $1^{\circ}, 22$.

38. Ibid., tomo $2^{\circ}, 21$.

39. Ibid., tomo $2^{\circ}, 22$. 


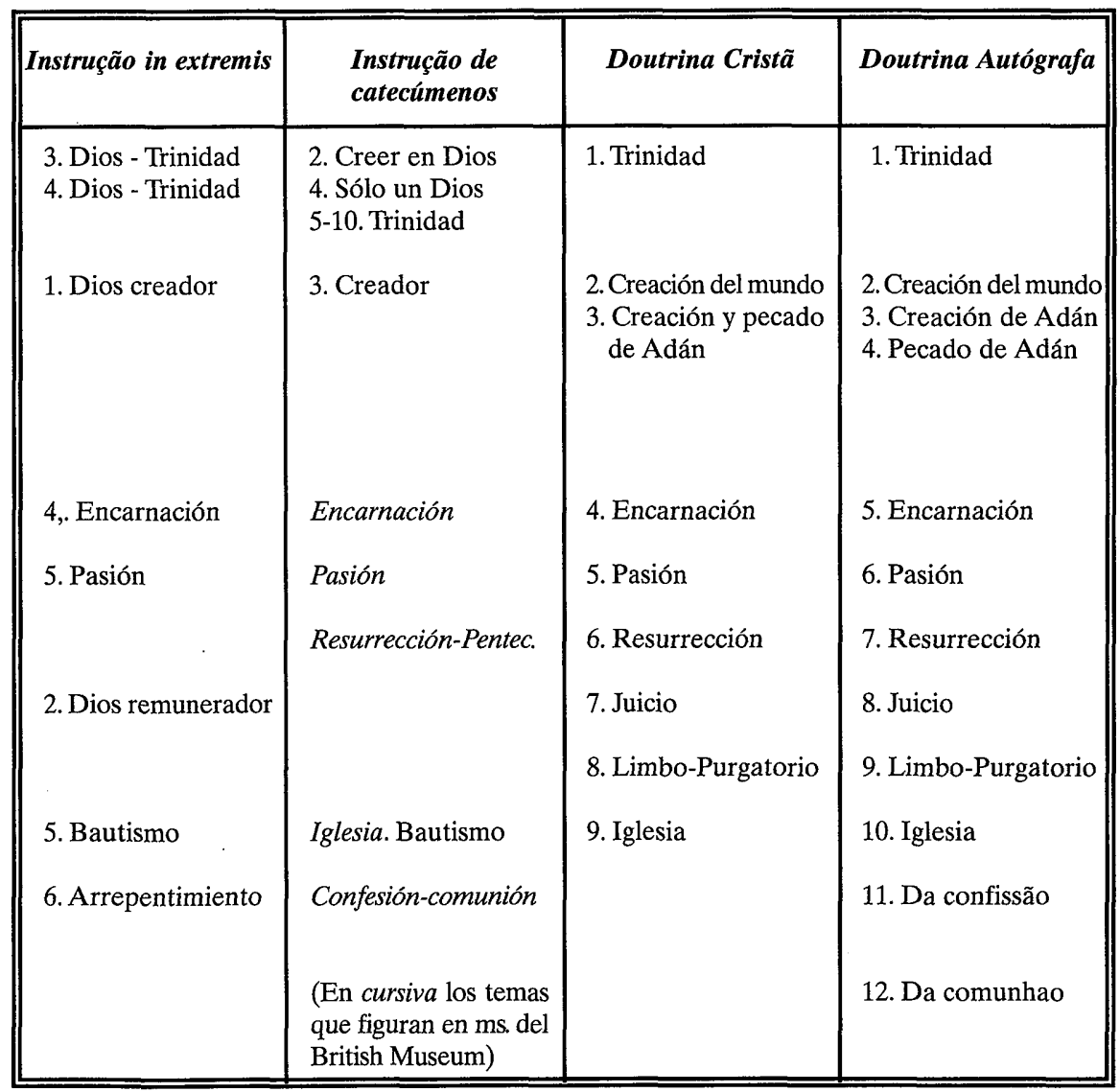

El autor, redactor y revisor de esta Doutrina autógrafa es Luis de Grã. José de Anchieta es el traductor de este escrito, bajo el nombre de Diálogo da Doutrina Cristã, en su utilización, junto con el resto de los escritos que integraban el conjunto conocido con el título de Doutrina Cristã, es decir, su primera y más antigua redacción.

Pero no terminó ahí la intervención de Anchieta, puesto que años después de redactada y traducida al tupi, Anchieta la traduce al portugués, además de proceder a una reelaboración de la misma. Cardoso, en su introducción correspondiente, describe así la participación de Anchieta:

«Já muito mais tarde, em idade avançada, o Apóstolo [= Anchieta] o reverteu para o português, prevendo talvez a extinção paulatina do tupi entre o povo da colônia. Apoiado en sua excelente memória, reproduziu todo o 
texto, modificando algunas poucas questões, que ficaram sem correspondente em tupi, mas que se podem facilmente reconstituir, como dissemos» 40 .

Que lo efectuó siendo de edad avanzada resulta indiscutible al contemplar la letra en la reproduccción facsímil. En cambio, que llevara a cabo la versión al portugués, previendo la desaparición de la lengua tupi, puede ser una hipótesis verosímil, pero no es segura, ni tiene menos fuerza que otras hipótesis posibles (que efectuara la traducción para responder a la demanda de alguien que no supiera tupi, o que le hubiera sido pedida para enviarla a la metrópoli). Más aún, la supuesta desaparación del tupi justificaría la traducción al portugués, pero no justifica suficientemente la reelaboración de la obra. También es gratuito que lo hiciera de memoria, puesto que nada demuestra que lo hiciera así; y es perfectamente verosímil que tuviera ante sí una copia en tupi, que fuera retocando a medida que la vertía al portugués.

Ya ha habido ocasión de comprobar que los nueve apartados que aparecen en la versión tupi, se han convertido en diez en la versión autógrafa portuguesa, porque el tercero, sobre la creación y pecado de Adán, se ha desdoblado en dos, aunque en realidad no ha modificado sensiblemente su contenido 41. Otro asunto es la adición de las dos partes sobre confesión y comunión en la versión portuguesa. Comparando globalmente cada apartado, encontramos las principales diferencias siguientes:

Apartado 1: Dios y la Trinidad. Tiene 22 preguntas en la versión tupi y 21 en la versión autógrafa, como consecuencia de haber suprimido la pregunta $4^{\text {a }}$ del tupi, que habla de las tres personas en la Trinidad, pues vuelve a mencionarlas en la pregunta $6^{2}$.

Apartado 2: Creación del mundo. Tiene 13 preguntas en la versión tupi y 14 en la versión autógrafa portuguesa: ha añadido una pregunta que afirma que Dios solo es el principio de todo.

Apartado 3: Creación del mundo. Ya he advertido que en la versión autógrafa se desdobla en dos apartados (creación del hombre; y pecado de Adán). Tiene 14 preguntas en la versión tupi, y sólo 12 en la versión portuguesa: han desaparecido las preguntas $3^{\text {a }}$ (que afirma que la tierra es en verdad la carne de la gente), y la $10^{\mathrm{a}}$ (que afirma, curiosamente, que Dios crió a Adán ya casado).

Apartado 4: Pecado de Adán. Las 13 preguntas de la versión tupi se han con-

40. Ibid., tomo $2^{\circ}, 22$.

41. La transcripción de Cardoso añade títulos a cada apartado, que no figuran en el manuscrito. También añade a la transcripción las abreviaturas M (=Maestro) y D (=Discípulo), ausentes del manuscrito. Hay además un error de numeración correlativa en las preguntas sobre la pasión. 
vertido en 15 en la versión autógrafa portuguesa. Esto es consecuencia de haber desdoblado la pregunta $9^{\mathrm{a}}$ del tupi (antes del pecado no sufriría nadie), en tres preguntas distintas en la otra versión (no habría tristezas, enfermedades ni muerte; las mujeres no tendrían dolores de parto; y no harían mal las cobras, onzas y otras cosas). También la pregunta $12^{\mathrm{a}} \mathrm{del}$ tupi (Adán pagó su pecado sufriendo dolores) se ha desdoblado en dos en la versión autógrafa (tuvo dolor de su pecado; e hizo penitencia de él). Apartado 5: Encarnación. En la versión tupi había 13 preguntas; en la versión autógrafa han salido 17 preguntas, porque ha añadido una pregunta en el sentido de que Jesús era pequeño, como nosotros, en el vientre de su madre; otra sobre que estuvo nueve meses en su seno; otra sobre que María no tuvo dolores de parto; y otra sobre que los seguidores de Jesús se llamaron Apóstoles y discípulos. Además, ha cambiado el sentido de la pregunta $12^{\mathrm{a}}$ del tupi que indicaba que sus contemporáneos conocieron que Jesús era Dios por sus resurrecciones y curaciones, por otra pregunta en que dice que hizo milagros (no se refiere a resurrecciones ni curaciones) para que conociesen que era Dios.

Apartado 6: Pasión. Son 28 las preguntas en la versión tupi, que han quedado en 26 preguntas. Ha suprimido una pregunta de la versión primera, la $12^{a}$ que afirmaba que Jesús quiso voluntariamente su muerte, sin librarse de sus enemigos; y dos preguntas, las $14^{\mathrm{a}}$ y $15^{\mathrm{a}}$ de la versión tupi han sido fundidas en una sola en la versión autógrafa, al indicar que murió por nosotros para que fuéramos al cielo (hay, además un cambio en esta pregunta, porque el amor por nosotros del tupi, se ha modificado en el amor de Dios en la versión autógrafa portuguesa). Otra pregunta que sufre una modificación es la $20^{\mathrm{a}}$ de la versión tupi que habla de que tras la muerte, Cristo fue al centro de la tierra, mientras que la versión autógrafa, en la pregunta equivalente, dice que fue al limbo.

Apartado 7: Resurrección, Ascensión. El cambio es muy notable en este apartado. La versión primitiva tupi incluye 21 preguntas, que abarcan tres temas: Resurrección, Ascensión y Pentecostés. En cambio, al hacer la versión portuguesa, autógrafa, aparecen sólo 13 preguntas, porque ha suprimido todo lo relativo a Pentecostés. No es un cambio irrelevante, sino todo lo contrario.

Además, en las preguntas sobre Resurrección - Ascensión, ha habido modificaciones introducidas por Anchieta en la versión autógrafa, pues la pregunta $5^{\mathrm{a}}$ del tupi, que dice que las heridas de manos, pies y costado también resucitaron con Jesús (¡curiosa expresión!), la ha cambiado añadiendo otra pregunta en que afirma que el sentido era para que dicha heridas fueran señales ciertas de la resurrección. Añade en la versión autógrafa, además, 
otras cinco preguntas, que respectivamente tratan de que Jesús resucitado se apareció a su Madre, mujeres y apóstoles; que estuvo con ellos cuarenta días; que le vieron subir al cielo más de 500 personas; que ascendió desde el monte Olivete; y que ascendió con su poder divino. Es palpable, aunque sólo fuera por este apartado, que la intervención de Anchieta no se limita a pasar al portugués un texto en tupi, sino que interviene activa y decisivamente.

Apartado 8. Juicio universal. La versión primera tupi tiene 31 preguntas. La versión autógrafa sólo tiene 29. Pero no se trata de la eliminación de dos cuestiones, sino de una actuación más a fondo. La primera pregunta sobre que volverá como Juez es igual en ambos escritos. Las preguntas que siguen, hasta recuperar el paralelismo de los textos, puede seguirse más fácilmente en este esquema:

\begin{tabular}{||l|l||}
\hline \multicolumn{1}{|c|}{ Diálogo da Doutrina Cristã } & \multicolumn{1}{c|}{ Doutrina Autógrafa } \\
\hline 2. Vendrá Jesús cuando la tierra deje de & \multicolumn{1}{c||}{ 2. No se sabe cuándo será el juicio. } \\
arder. & 3. Antes habrá muchas y temerosas señales. \\
3. Pues arderá todo. & $\begin{array}{l}\text { 4. Son las que dice nuestro Señor en el } \\
\text { Evangelio. }\end{array}$ \\
4. No escapará nada. & $\begin{array}{l}\text { 5. Algunas son: guerras, pestes, hambre, } \\
\text { terremotos, oscuridad, inundaciones. }\end{array}$ \\
5. Ni las personas. & 6. Todos han de resucitar. \\
6. Después la gente volverá a vivir. & 7. Lo harán por el poder de Dios que crió \\
7. Entrará de nuevo el alma en los cadáve- & todo de la nada. \\
res. & \\
8. Serán llamados por los ángeles. & \\
9. Los cadáveres se levantarán inmediata- & \\
mente. & \\
10. Todas las almas vendrá desde el cielo, el & \\
purgatorio o el infierno. & \\
11.El cuerpo de los buenos será muy her- & \\
moso. & \\
12. El cuerpo de los malos será muy feo. & \\
\hline \hline
\end{tabular}

Más que cualquier comentario, parece evidente que hay que convenir en que los cambios de planteamiento son fundamentales. No terminan ahí los cambios, porque la versión autógrafa incorpora, además, otras tres preguntas: una sobre quiénes son los buenos (los bautizados, que creen en Jesús y no quebrantan los mandamientos); otra sobre quiénes son los malos (exactamente en el sentido contrario); y otra tercera, sobre que en el cielo los salvados no han de comer ni casarse, pues serán como los ángeles.

No es posible cerrar esta exposición sin hacer referencia a algo que ya ha salido, y es que en la pregunta $4^{\text {a }}$ de la versión autógrafa, habla de las señales del fin del mundo, remitiendo expresamente a lo que Jesús dice en el Evangelio ( Os que Cristo Senhor Nosso diz no Evangelho»): es la única ocasión en que se remite de forma expresa a la palabra de Dios como fuente de 
autoridad que ratifica las afirmaciones de la catequesis y del catequista. Rara avis.

Apartado 9: Limbo. También ha experimentado cambios. Las versión tupi tenía 19 preguntas, de las cuales han desaparecido, al reelaborarlo, dos (la de que todo el mundo nace con el pecado original; y la excepción de la Virgen María): quedan, pues, 17 preguntas. éstas se han vista incrementadas con cuatro preguntas más en la reelaboración de la versión autógrafa: los no bautizados irán al infierno; los niños no bautizados irán al limbo; allí no han de padecer fuego; y los del purgatorio tiene la certeza de que han de salir de él. Total, 21 preguntas en la versión autógrafa portuguesa.

Apartado 10: La Iglesia. Casi sin cambios, pues hay 31 preguntas en la versión tupi, que cambian a 32 en la versión portuguesa autógrafa, al añadir una pregunta que afirma que Dios da bienes temporales a los buenos y -precisamente esta es la adición- también virtudes para el alma. Una modificación reseñable es que la versión tupi decía (pregunta $4^{\mathrm{a}}$ ) que los miembros de la Iglesia comunican entre sí; y la versión autógrafa añade que comunican por medio de disciplinas, ayunos y oraciones.

La versión autógrafa añade también otros dos apartados, uno sobre la confesión y otro sobre la comunión. Sobre ello, Armando Cardoso da una explicación, que no me parece demasiado segura:

«Estes dois últimos assuntos e nessa ordem, nos mostram que este Sumário da Fé era o que todos deviam saber, antes de serem admitidos à prática da Confissão e Comunhão. Por isso tambén se encontran separados, e en certo modo em duplicata, no final da Doutrina Cristã en tupi: os últimos tirados do Diálogo da Fé, ao qual pertencem, pois aí estão faltando, com clamorosa surpresa, entre os diálogos finais, adicionados ao manuscrito da Doutrina Cristã, foran transcritos por copista de letra toda diferente» 42 .

Hay una verdad catequética importante en la intuición de Cardoso: que después de saber todo lo anterior, seguían las explicaciones de los sacramentos de penitencia y eucaristía, y sin los conocimientos previos no eran admitidos los indígenas a dichos sacramentos. Pero hay otra afirmación que no comparto tan fácilmente: la de asegurar que las explicaciones de estos sacramentos se encuentran separadas, y duplicadas. Vamos por partes. En Diálogo da $F e ́$, no sólo no se encuentra duplicada, sino que falta -como Cardoso también constata- en la explicación de los sacramentos; en Doutrina Cristã aparece el apartado $6^{\circ}$, «Diálogo dos sacramentos», en el que están integrados todos los

42. Ibid, tomo $2^{\circ}, 20, \mathrm{y}$ tomo $1^{\circ}, 23$. 
sacramentos; a continuación aparecen en el ms. que responde a la sigla ARSI, Opp. NN. 22 dos hojas, evidentemente de otra letra, que comienzan en f. 47v y llegan hasta el 50v, que contienen «da confissao» y «da comunhao». En segundo lugar, en la misma obra (Doutrina Cristã) el apartado $3^{\circ}$, «Diálogo da Doutrina Cristã» no contiene, al final, ninguna explicación sobre penitencia y eucaristía, como hace su paralelo, Doutrina Autógrafa. En tercer lugar, como ya está indicado, Doutrina Autógrafa incluye dos partes más que su paralelo, sobre penitencia y eucaristía.

Cardoso, en actitud voluntariosa y queriendo suplir la inexplicable carencia de estos temas en Diálogo da Fé, se limita a trasvasar la explicación de penitencia y eucaristía que aparece en el manuscrito indicado (ARSI, Opp. NN. 22, f. 47v-50v) a fin de rellenar la ausencia detectada 43 . Trasvasa con muy buena voluntad, pero con muy escaso rigor científico, cosas de un manuscrito a otro, en una operación de maquillaje que deje bien parado un manuscrito incompleto. En caso de proceder a un trasvase, ¿no hubiera sido más riguroso trasladar esos f. $47 \mathrm{v}-50 \mathrm{v}$, dentro de las versiones manuscritas de la misma obra, al final del «Diálogo da Doutrina Cristã»? De hacer procedido así, hubieran quedado el «Diálogo da Doutrina Cristã» con 9 apartados, más los apéndices de confesión y comunión, prácticamente idéntico en su estructura a Doutrina Autógrafa, con 10 apartados (por la subdivisión del apartado $3^{\circ}$ ), y además ambos apéndices.

Pero la preocupación perfeccionista de "borrar" la mancha del silencio sobre esos dos sacramentos, le lleva a violentar los manuscritos, que, a la hora de recopilarse, redactaron las cosas de esta manera, y no de otra. En todo caso, lo verdaderamente serio es no tratar de completar lo que falta en un manuscrito, sino presentarlo como está, incluso con sus fallos. Pero desear perfeccionarlo trasvasando cosas de un sitio para otro, resulta poco respetuoso con los originales. Sólo serias razones, avaladas y documentadas, pueden justificar un proceder semejante, simplemente porque faltan en Diálogo da $F e ́$, y limitarse a decir que pertenece a esa obra (porque falta en ella) lo que aparece en otra, me parece inaceptable.

Comparando las dos versiones, la que consta en el manuscrito de Doutrina Cristã (tan desgraciadamente trasvasada a donde no estuvo nunca) y la que aparece en el manuscrito de Doutrina Autógrafa se ve con claridad que las explicaciones sobre penitencia y eucaristía son iguales, salvo escasas diferencias. Por lo tanto, si a Cardoso le urge trasvasar lo correspondiente a una

43. El único indicio de esta manipulación consta en la edición de Diálogo da Fé,140, donde aparecen las referencias a las respectivas páginas del manuscrito $\mathrm{DC}_{1}$ y $\mathrm{DC}_{2}$, para comunión; e Ibid., 144, donde aparecen las referencias para la confesión. 
versión, para llenar la laguna de Diálogo da Fé, por la misma razón debería haber trasvasado las dos, pues no había razón para hacerlo con una y no con la otra. $\mathrm{O}$ mejor, no haberlo hecho con ninguna. La identidad casi absoluta entre las dos versiones de lo relativo a penitencia y eucaristía debería haber llevado a Cardoso al convencimiento de que, de tener que hacer un desplazamiento, tendría que haber colocado lo relativo a confesión y comunión al final del «Diálogo da Doutrina Cristã», apartado $3^{\circ}$ de Doutrina Cristã.

Dejando ya esta cuestión, y retornando al conjunto de Doutrina Autógrafa, un análisis con un poco más de profundidad me parece que indica un sutil, pero real nivel de penetración del cristianismo en la redacción de esta obra tardía, en su versión portuguesa. Se han producida en ella una serie de cambios, a veces inapreciables, pero que, en comparación con las partes equivalentes de la doctrina enseñada en los otros libros o en sus apartados correspondientes, revelan un estilo distinto.

Así, suprime en Doutrina Autógrafa una pregunta demasiado burda, según la cual la tierra es la carne de las personas (creación del hombre), que podría servir para una explicación rudimentaria, pero no para otra un poco mejor. Igualmente, en la creación del hombre, suprime la desconcertante pregunta de que Dios creó a Adán casado (aunque luego hable de la mujer, de la operación de costilla). Añade (respecto a Doutrina Cristã) que las mujeres no tendrían dolores de parto (si no hubiera habido pecado original); añade que las cobras y onzas no harían mal a los hombre; y que Adán hizo penitencia de su pecado. En el tema de la Encarnación, cambia el circunloquio «mujer no tocada por hombre» (Doutrina Cristã) por «mujer virgen» (Doutrina Autógrafa); ofrece en ésta segunda una explicación más amplia de los milagros de Jesús; y añade que los que creyeron en Él se llamaban «apóstoles y discípulos». En la explicación de la pasión substituye el circunloquio «fuego del infierno» por el término más propio de «infierno»; y también alude a la insuficiencia de nuestra «penitencia» para salvarnos (término más propio); igualmente substituye el término poco exacto de «centro de la tierra» por el de «limbo», como comentario al descenso de Cristo a los infiernos. En el apartado sobre el juicio final, en Doutrina Autógrafa hace una llamada expresa al Evangelio, que no aparecía en Doutrina Cristã; precisa con mucho mayor rigor y exactitud las tres condiciones que diferencian a los buenos de los malos; y aporta el dato (cercano a una cita textual) de que los salvados ni comerán, ni se casarán, sino que serán como ángeles (Mt. 22, 30). Finalmente, en el apartado sobre la Iglesia, hay más precisión en Doutrina Autógrafa en que sus miembros comunican entre sí en disciplinas, ayunos y oraciones; en que Dios da sus virtudes a las almas de los buenos; en la expresión de que Jesucristo es «cabeza de la Iglesia» (Doutrina Autógrafa), aparece más preci- 
sión que en la de que es «jefe de los buenos cristianos»; lo mismo ocurre al hablar de «Papa» o al hablar de «gran sacerdote»; y también al decir que el «Espíritu Santo es regidor de la Iglesia», que al decir que «guarda la Iglesia». Son todo ello sutiles indicios de un mayor nivel de perfeccionamiento en la presentación de la fe cristiana, que están apuntando la idea de que una mayor penetración de cristianismo permite expresar con mayor exactitud lo mismo. Sin embargo no es posible olvidar que, al utilizar el portugués en Doutrina Autógrafa, Anchieta disponía de unos medios de expresión que no estaban a su alcance en la lengua tupi, en la que está redactada Doutrina Cristã: Quizá es sólo una impresión ficticia de la mayor penetración del cristianismo lo que podría ser atribuido a la diferente precisión de la lengua.

La intervención, por tanto de José de Anchieta sobre Doutrina Autógra$f a$, no es simplemente la de hacer una simple versión al portugués, sino que resulta mucho más profunda y digna de consideración.

\section{La cuestión del Confessionario.}

No he sido partidario de incluir los confesionarios o confesionales entre los instrumentos catequéticos, porque su empleo directo es diverso. No se puede gratuitamente identificar todo como instrumentos de la misma categoría, por cuanto han sido pensados, redactados y empleados con finalidad diversa. Cierto que son afines. Pero no todo lo que constituye, en sentido amplio, la educación de la fe es catequético en el sentido propio del término.

Por esa razón, difiero del criterio respetable de Armando Cardoso de incluir el Confessionario como instrumento catequético. Cierto que consta en los mismos manuscritos en que aparece Doutrina Cristã, pero este sólo hecho no lleva a poner en pie de igualdad lo que son herramientas pastorales diversas. Es obra directa de Anchieta, que puede ser valorada y estudiada en otro trabajo diverso del presente, consagrado a sopesar y dar a conocer lo fundamental de los trabajos catequéticos de José de Anchieta.

Por último, me parece poco fiable el criterio excesivamente amplio que utiliza Armando Cardoso, de localizar obras, o identificarlas, sin tener certeza plena. En efecto, recogiendo unos cuantos textos de una serie de cartas contemporáneas de Anchieta, en que se habla de la actividad de los misioneros, y en particular de la actividad catequética, compone un argumento con las frases entresacadas, con el que no estoy de acuerdo. Cardoso dice:

«Estas expressões "Doutrina e rudimentos da fé... un formulário de perguntas...fazendo um de Mestre e outros de Discipulos... conhecimento da Santisima Trindade e mistérios da vida de Cristo... quando lhes for perguntado saibam responder", tudo isso vem a significar o Diálogo da Doutrina 
Cristã, en sua forma mais breve, isto é, a Instrução de Catecúmenos, que seria depois amplificada por Luís de Grã e a ele especialmente atribuída» ${ }^{44}$.

No son más que frases genéricas que hacen referencia, de diversas formas y con ocasiones también distintas a la actividad catequética, descrita en forma general; deducir de tales frases la identificación con una determinada obra es forzar los textos, para llevarlas a decir lo que no dicen realmente.

En el testimonio de Quiricio Caxa, aparecía consignado entre las obras catequéticas de Anchieta, además, un escrito titulado As coisas necessárias para a doutrina, que, a mi modo de ver, no se identifica plenamente con ninguna de los anteriores, ni con ninguna de sus correspondientes partes. Quizá se trata de una obra no localizada, o una simple descripción genérica, que no me parece corresponda, ni por título aproximado, ni por contenido, con alguna de las ya aparecida. Queda la incógnita.

Luis Resines, Pbro. Estudio Teológico Agustiniano VALLADOLID

44. Diálogo da Fé, ed. citada, 27; también en Doutrina Cristã, tomo $1^{\circ}, 28$; y tomo $2^{\circ}, 22$. 